\title{
Ten Years-Snapshot of the Occurrence of Emerging Contaminants in Drinking, Surface and Ground Waters and Wastewaters from São Paulo State, Brazil
}

\author{
Cassiana C. Montagner, ${ }^{\circledR *}{ }^{* a, b}$ Fernando F. Sodrée, ${ }^{\circledR c}$ Raphael D. Acayaba, ${ }^{\circledR b}$ \\ Cristiane Vidal, ${ }^{\oplus a}$ Iolana Campestrini, ${ }^{a}$ Marco A. Locatelli, ${ }^{d}$ Igor C. Pescara, ${ }^{e}$ \\ Anjaína F. Albuquerque, ${ }^{\circ b}$ Gisela A. Umbuzeiro ${ }^{b}$ and Wilson F. Jardim ${ }^{a}$ \\ aInstituto de Química, Universidade Estadual de Campinas (UNICAMP), \\ CP 6154, 13083-970 Campinas-SP, Brazil \\ ${ }^{b}$ Faculdade de Tecnologia, Universidade Estadual de Campinas (UNICAMP), \\ 13484-332 Limeira- SP, Brazil \\ cInstituto de Química, Universidade de Brasília, 72919-910 Brasília-DF, Brazil \\ ${ }^{d}$ Redox Consultoria e Remediação Ambiental, Rua Maria Spinelli Bruni, 93, 13309-091 Itu-SP, Brazil \\ ${ }^{e}$ Instituto Federal de Educação, Ciência e Tecnologia Goiano, 75901-970 Rio Verde-GO, Brazil

\begin{abstract}
Emerging contaminants have been considered one of the main concerns for ensuring the quality of water around the world. This work presents the results of 10 years of analyses carried out in the state of São Paulo (Brazil) that has the high population density and intense agricultural and industrial activities. In this work 58 compounds ( 9 hormones, 14 pharmaceuticals and personal care products, 8 industrial compounds, 17 pesticides and 10 illicit drugs) were determined from 2006 to 2015 in 708 samples including raw and treated sewage, surface and ground and drinking waters. A preliminary risk assessment for aquatic life protection identified potential risks for caffeine, paracetamol, diclofenac, 17 $\alpha$-ethynylestradiol, 17 $\beta$-estradiol, estriol, estrone, testosterone, triclosan, 4- $n$-nonylphenol, bisphenol A, atrazine, azoxystrobin, carbendazim, fipronil, imidacloprid, malathion and tebuconazole. Drinking water criteria were available only for 22 compounds and for them no adverse effects were expected at the concentrations found, except for $17 \beta$-estradiol.
\end{abstract}

Keywords: risk assessment, pesticides, hormones, DWTP, WWTP

\section{Introduction}

A large number and quantity of substances are produced and consumed around the world to improve human life quality in a variety of activities, such as the protection of crops, the treatment of diseases, which has increased people's life expectance, or just to improve the comfort of everyday life. Residues of these substances reaches the environment through different pathways contaminating soils, waters and the atmosphere. Some of them are classified as emerging contaminants, i.e., natural or anthropogenic substances of emerging concern that are not commonly monitored but are found in the environment and may cause known or suspected adverse effects in the humans or wildlife. ${ }^{1}$ Pesticides, pharmaceuticals and personal care products, hormones,

\footnotetext{
*e-mail: montagner@iqm.unicamp.br
}

sunscreen/UV filters, illicit drugs, perfluorinated compounds, disinfection by-products, nanomaterials, microplastics, are among the most investigated substances. ${ }^{2}$

In fact, innumerous contaminants of emerging concern are being increasingly investigated around the world since pioneers works revealed negative effects on the reproduction of fish related to the presence of natural and synthetic hormones coming from wastewater treatment plants (WWTPs) discharges. ${ }^{3,4}$ Although some emerging contaminants may demonstrate low acute toxicity, many of them are able to cause significant effects on the metabolism of living organisms at very low concentrations, i.e., around nanogram or microgram per liter, in a chronic exposure scenario and can affect the health of aquatic organisms as well as humans. ${ }^{1}$

Over the past recent years, several studies have shown that these contaminants are not necessarily new molecules, 
but rather substances that were recently detected due to the improvement of analytical instrumentation that allowed the development of multi-residue methods that are capable of measure low concentrations of these contaminants in different water matrices such as surface, ground and drinking waters. ${ }^{2}$

Occurrence data has been obtained over the years, which allowed the assessment of quality of waters by risk assessment approaches. Monitoring studies carried out in different countries ${ }^{5-10}$ provide important information to the establishment of which compounds are the most relevant in each region, according to their social and economic characteristics. The quality and quantity of available data on the occurrence and effects of such contaminants have allowed the elucidation of contamination scenarios, as well as proposal of priority list of compounds considering their toxicity, concentration and/or frequency of detection in each region. This important step should be done before starting a regulation process, when it is necessary to choose few indicators in a list that includes thousands of non-regulated contaminants present in the environment. ${ }^{11}$

This work was carried out in São Paulo state (Brazil), which has the highest density population in the country and 41 million inhabitants. It is also the most developed State, responsible for almost $30 \%$ of Brazilian gross domestic product (GDP). The most demanding activity for water is irrigation, followed by industrial, livestock and drinking water. $^{12}$

In a recent review about emerging contaminants in different Brazilian aquatic matrices, a list of 56 papers published between 1997 and 2017 reveal the occurrence of around two hundred compounds in waste, surface and drinking waters from 11 of the 26 states and Federal District. $^{7}$ The Southeastern region presented the largest number of studies ${ }^{7}$ especially in the state of São Paulo, which has high patterns of consumption, similar to developed countries. However, this region also accumulates environmental problems that are typical to developing countries, especially related to the poor sanitation, where not all waste waters are properly treated before being released to surface waters. Depending on the level of contamination, several uses of water have been impaired. ${ }^{13}$

In this paper occurrence data of 58 emerging contaminants of the 708 samples of drinking, surface, ground and waste waters (sampled in the state of São Paulo, Brazil, between 2006 and 2015) were collected to perform a preliminary risk assessment for two of the multiple uses of water, i.e., aquatic life protection and drinking water. The data were retrieved from different researches developed in the Environmental Chemistry Lab from the State University of Campinas, including published papers and unpublished data that were produced using the analytical methods developed in the research group.

\section{Experimental}

\section{Standards and reagents}

Reference standard reagents (purity > 97\%) were purchased from Sigma-Aldrich (Steinheim, Germany), Riedel-de Haën (Seelze, Germany) or Fluka Analytic (Milwaukee, USA) as powders, except cocaine and benzoylecgonine solutions, that were purchased from Cerilliant Corporation (Round Rock, USA) at concentrations of 0.1 or $1.0 \mathrm{mg} \mathrm{mL}^{-1}$ in acetonitrile (purity $>98 \%)$. Formic acid (98\%) and ammonium formate (98\%), used as mobile phase additive, were acquired from Sigma-Aldrich (St. Louis, USA) and Riedel-de Haën (Seelze, Germany), respectively. Methanol and acetonitrile (HPLC grade) were obtained from J. T. Baker (Xalostoc, Mexico). Hydrochloric acid (37\%) was provided by Mallinckrodt (Paris, France). Acetone, purchased from Tedia (Fairfield, USA), was used for glassware cleaning. Ultrapure water $(18.2 \mathrm{M} \Omega \mathrm{cm})$ was produced using a Milli-Q Plus purification system (Millipore, Molsheim, France).

Solid phase extraction (SPE) cartridges OASIS HLB $6 \mathrm{cc}, 500 \mathrm{mg}$ (Waters, Milford, USA) were used for all compounds. Anionic-exchange cartridges $500 \mathrm{mg}$ Strata SAX (Phenomenex, Torrance, USA) were used to remove humid substances before antimicrobials extraction. Glass fiber filters, used to preliminary filtration of the samples, were purchased from Sartorius Stedim Biotech (Goettingen, Germany).

Individual $400 \mathrm{mg} \mathrm{L}^{-1}$ stock solutions were prepared by dissolving appropriate amounts of each standard in methanol and kept in amber glass bottles at $4{ }^{\circ} \mathrm{C}$. Working solutions in the range from 0.005 to $10 \mathrm{mg} \mathrm{L}^{-1}$ were prepared by diluting appropriate aliquots of the stock solutions. Quantification was performed using external calibration according to Miller and Miller. ${ }^{14}$

\section{Study site and sample collection}

Occurrence data considered a total of 708 samples, including raw and treated wastewaters, surface, ground and drinking waters, collected in the state of São Paulo at different locations and times between 2006 and 2015 (Figure 1). Sampling locations were selected to represent urban areas with variable population densities and industrial activities. In addition, rural areas with different crop production were also included in this study. Details 
on sampling sites can be found in the Supplementary Information (SI) section.

Water samples were collected in amber glass bottles previously decontaminated with a detergent solution, tap and distilled water, and then rinsed with ethanol and acetone before baking at $400^{\circ} \mathrm{C}$ for $4 \mathrm{~h}$. All containers were wrapped with aluminum foil. Before sampling, bottles were firstly rinsed and then, completed with the sampled water. Then, they were sealed and transported in a thermal cooler to the laboratory. Samples were kept refrigerated $\left(4^{\circ} \mathrm{C}\right)$ until the extraction procedures within $48 \mathrm{~h}$.

\section{Analytical methods}

The number of investigated compounds at Environmental Chemistry Lab has continuously increased over the years. Therefore, not all compounds were analyzed for all samples. Fifty eight emerging contaminants including 9 hormones, 13 pharmaceuticals and 1 personal care products, 8 industrial compounds, 17 pesticides and 10 illicit drugs, were quantified by liquid chromatography coupled to triple quadrupole mass spectrometry (LC(ESI) MS/MS) ${ }^{15-19}$ (Agilent Technologies, USA) or high performance liquid chromatography coupled to ultravioletdiode array (HPLC-UV/DAD) or molecular fluorescence (HPLC-FLD) detectors (Shimadzu Corporation, Japan). ${ }^{20}$ The methods used to quantify the emerging contaminants were already published. ${ }^{15-20}$ Details about the methodology used for each sample are described in the SI section.

Acetaminophen, acetylsalicylic acid, diclofenac, ibuprofen, caffeine, estrone, 17ß-estradiol, progesterone, $17 \alpha$-ethynylestradiol, levonorgestrel, diethylphthalate, dibutylphthalate, 4-nonylphenol, 4-octylphenol and bisphenol A were determined in 36 surface water samples from six different water bodies (Atibaia River,
Capivari River, Jundiaí River, Anhumas Creek, Pinheiros Creek and Salto Grande Dam) and in 16 drinking water samples collected between 2006 and 2008 using SPE and HPLC-UV/DAD and HPLC-FLD according to Montagner and Jardim. ${ }^{20}$

The antimicrobials amoxicillin, ampicillin, cefalexin, ciprofloxacin, norfloxacin, sulfamethoxazole, tetracycline and trimethoprim were investigated in 13 surface water samples from the Atibaia River Basin during 2009-2010 using SPE and LC(ESI)-MS/MS according to Locatelli et al. ${ }^{17}$

Caffeine, triclosan, 4- $n$-octylphenol, 4-n-nonylphenol, bisphenol A, phenolphthalein, atrazine and the hormones estrone, 17 $\beta$-estradiol, estriol, progesterone, testosterone, $17 \alpha$-ethynylestradiol, mestranol, levonorgestrel and diethylstilbestrol were investigated in 25 raw and treated sewage samples, 269 surface water samples from 10 water bodies (Atibaia River, Capivari River, Corumbataí River, Piracicaba River, Sorocaba River, Baixo Cotia River, Anhumas Creek, Preto River, Salto Grande Dam and Tanque Grande Dam), 33 groundwater samples and 265 drinking water samples from 13 different cities using SPE and LC(ESI)-MS/MS according to Jardim et al..$^{18}$ and Machado et al. ${ }^{19}$

Amphetamine-type stimulants such as amphetamine, methamphetamine, 3,4-methylenedioxyamphetamine hydrochloride (3,4-MDA), 3,4-methylenedioxy$\mathrm{N}$-ethylamphetamine hydrochloride (3,4-MDEA) and 3,4-methylenedioxymethamphetamine (3,4-MDMA), as well as the opioids morphine, morphine-glucuronide and 6-acetylmorphine were determined in 18 surface water samples collected in Atibaia River Basin in 2010. Cocaine, benzoylecgonine and the pesticides simazine, ametryn, difenoconazole, epoxiconazole, flunquinconazole, tebuconazole, azoxystrobin, picoxystrobin, pyraclostrobin,

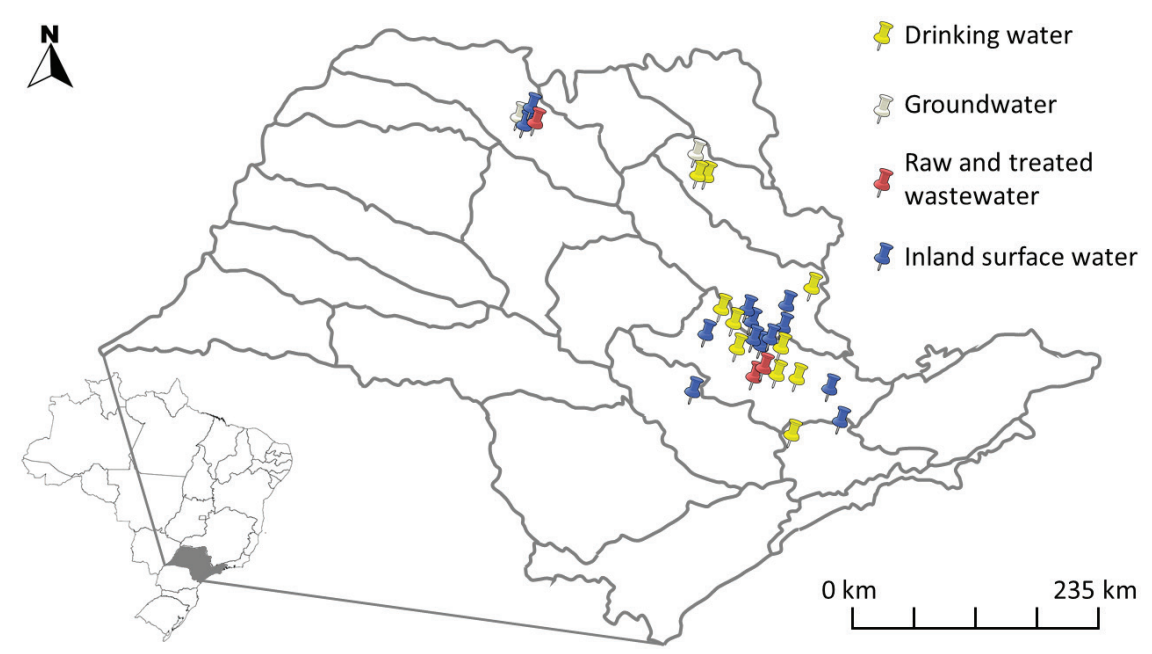

Figure 1. Map of the state of São Paulo, Brazil, including the sampling points from different matrices. 
trifloxystrobin, imidacloprid, chlorpyrifos, profenofos, fipronil, malathion, carbendazim, bromacil and clomazone were determined in 126 surface water samples from 17 water bodies (Atibaia River, Capivari River, Corumbataí River, Piracicaba River, Jaguari River, Camanducaia River, Mogi Guaçu River, Mogi Mirim River, Pirapitingui River, Anhumas Creek, Pinheiros Creek, Cachim Creek, Cachoeira Creek, Tabajara Creek, Pires Creek, Pinhal Creek, and Tatu Dam) and in 33 drinking water samples from ten different cities between 2010 and 2015. Atrazine was determined in 199 surface waters samples and 126 drinking water samples during the same period using SPE and LC(ESI)-MS/MS according to Campestrini and Jardim $^{15}$ and Montagner et al. ${ }^{16}$

\section{Preliminary risk assessment}

Water quality criteria (WQC) were selected from peer-reviewed literature and/or from webpages of official environmental and health agencies around the world. Risk evaluation was performed in a worst-case scenario comparing the lowest water quality criteria found with the maximum environmental concentrations (MEC). The risk quotient method was employed dividing MEC by WQC. Values greater than one indicate that risk for the specific use of the water is expected. ${ }^{21}$ Water quality criteria for protection of aquatic life were used to assess the risk of surface waters. Drinking water quality criteria were used to assess the risk of water for human consumption.

\section{Results and Discussion}

\section{Surface water}

A total of three hundred and twenty-nine (329) samples of surface waters were collected in the state of São Paulo between 2006 and 2015. The number of samples analyzed, the frequency of positive samples and the concentration of each compound are presented in Table 1 and in the SI section. WQC for aquatic life protection were found for 33 of the 58 substances investigated and the selected criteria and the risk quotient of the worst scenario were also presented in Table 1. Figure 2 shows a plot representation of the concentrations and the preliminary risk assessment.

The number of analysis to each contaminant and the respective frequency of detection varied among samples (Table 1). Among the contaminants, the hormones $17 \beta$-estradiol and estrone, together with the synthetic hormone $17 \alpha$-ethynylestradiol, were the most frequently investigated substances (221 samples), followed by the industrial surfactants 4-n-octylphenol and 4- $n$-nonylphenol (205 samples) and by caffeine (203 samples). Eight other contaminants were investigated in more than 150 samples, including 6 hormones (155 to 191 samples), atrazine (199 samples) and triclosan (157 samples). Caffeine showed the highest frequency of detection $(97 \%)$ followed by atrazine $(69 \%)$, triclosan $(43 \%)$, estriol $(31 \%)$, estrone $(28 \%)$ and testosterone $(13 \%)$.

Table 1. Frequency of positive samples, concentration of the emerging compounds analyzed in surface water and the lowest aquatic life water quality criteria (WQC) found in the literature

\begin{tabular}{|c|c|c|c|c|c|c|c|c|c|c|c|}
\hline Class & Compound & CAS number & $\begin{array}{l}\text { Positive } \\
\text { samples }\end{array}$ & $\mathrm{n}$ & $\begin{array}{c}\text { Frequency / } \\
\%\end{array}$ & $\begin{array}{l}\text { Mean / } \\
\left(\text { ng L L-1) }^{-1}\right)\end{array}$ & $\begin{array}{c}\text { Min. / } \\
\left(\text { ng L L-1) }^{-1}\right.\end{array}$ & $\begin{array}{c}\text { Max. } \\
(\mathrm{MEC}) / \\
\left(\mathrm{ng} \mathrm{L}^{-1}\right)\end{array}$ & $\begin{array}{l}\text { WQC / } \\
\left(\mathrm{ng} \mathrm{L}^{-1}\right)\end{array}$ & Reference & $\begin{array}{c}\text { Risk } \\
\text { quotient }\end{array}$ \\
\hline \multirow{17}{*}{ 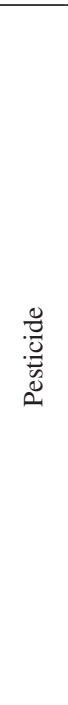 } & ametryn & $834-12-8$ & 33 & 86 & 38 & 17 & 0.1 & 148 & & & \\
\hline & atrazine & $1912-24-9$ & 137 & 199 & 69 & 30 & 1 & 611 & 10 & 22 & 60 \\
\hline & azoxystrobin & 131860-33-8 & 25 & 89 & 28 & 28 & 0.3 & 431 & 200 & 23 & 2 \\
\hline & bromacil & $314-40-9$ & 5 & 89 & 6 & 27 & 2 & 103 & 5000 & 24 & 0.02 \\
\hline & carbendazim & $10605-21-7$ & 82 & 91 & 90 & 158 & 0.8 & 4520 & 150 & 25 & 30 \\
\hline & clomazone & 81777-89-1 & 25 & 87 & 29 & 10 & 0.3 & 142 & 1000 & 26 & 0.1 \\
\hline & difenoconazole & $119446-68-3$ & 5 & 89 & 6 & 14 & 0.4 & 43 & 560 & 25 & 0.07 \\
\hline & epoxiconazole & $133855-98-8$ & 9 & 89 & 10 & 8 & 0.2 & 20 & 200 & 23 & 0.1 \\
\hline & fipronil & $120068-37-3$ & 24 & 63 & 38 & 10 & 1 & 22 & 12 & 27 & 1.8 \\
\hline & flunquinconazole & $136426-54-5$ & 8 & 77 & 10 & 17 & 2 & 36 & & & \\
\hline & imidacloprid & $138261-41-3$ & 42 & 89 & 47 & 13 & 1 & 68 & 13 & 23 & 5 \\
\hline & malathion & $121-75-5$ & 9 & 73 & 12 & 26 & 0.8 & 74 & 6 & 25 & 12 \\
\hline & picoxystrobin & $117428-22-5$ & 6 & 89 & 7 & 13 & 1 & 44 & & & \\
\hline & pyraclostrobin & $175013-18-0$ & 2 & 89 & 2 & 3 & 0.5 & 5 & 200 & 27 & 0.02 \\
\hline & simazine & $122-34-9$ & 14 & 86 & 16 & 9 & 1 & 31 & 180 & 11 & 0.2 \\
\hline & tebuconazole & $107534-96-3$ & 28 & 89 & 31 & 39 & 1 & 1071 & 240 & 23 & 4 \\
\hline & trifloxystrobin & $141517-21-7$ & 3 & 89 & 3 & 4 & 0.3 & 9 & 30 & 27 & 0.3 \\
\hline
\end{tabular}


Table 1. Frequency of positive samples, concentration of the emerging compounds analyzed in surface water and the lowest aquatic life water quality criteria (WQC) found in the literature (cont.)

\begin{tabular}{|c|c|c|c|c|c|c|c|c|c|c|c|}
\hline Class & Compound & CAS number & $\begin{array}{l}\text { Positive } \\
\text { samples }\end{array}$ & $\mathrm{n}$ & $\begin{array}{c}\text { Frequency / } \\
\%\end{array}$ & $\begin{array}{l}\text { Mean / } \\
\left(\mathrm{ng} \mathrm{L}^{-1}\right)\end{array}$ & $\begin{array}{l}\text { Min. / } \\
\left(\mathrm{ng} \mathrm{L}^{-1}\right)\end{array}$ & $\begin{array}{c}\text { Max. } \\
(\mathrm{MEC}) / \\
\left(\mathrm{ng} \mathrm{L}^{-1}\right)\end{array}$ & $\begin{array}{l}\text { WQC / } \\
\left(\operatorname{ng~L}^{-1}\right)\end{array}$ & Reference & $\begin{array}{c}\text { Risk } \\
\text { quotient }\end{array}$ \\
\hline \multirow{14}{*}{ 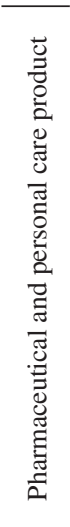 } & acetaminophen & $103-90-2$ & 2 & 34 & 6 & 6860 & 280 & 13440 & 9200 & 28 & 1.5 \\
\hline & acetylsalicylic acid & $50-78-2$ & 6 & 34 & 18 & 5978 & 476 & 20960 & 61000 & 29 & 0.3 \\
\hline & amoxycillin & $26787-78-0$ & 13 & 13 & 100 & 8 & 4 & 17 & & & \\
\hline & ampicillin & 69-53-4 & 2 & 13 & 15 & 1 & 1 & 1 & 75 & 30 & 0.01 \\
\hline & caffeine & $58-08-2$ & 197 & 203 & 97 & 4823 & 19 & 127000 & 5200 & 31 & 24 \\
\hline & cephalexin & $15686-71-2$ & 13 & 13 & 100 & 22 & 11 & 29 & 2500 & 30 & 0.01 \\
\hline & ciprofloxacin & $85721-33-1$ & 11 & 13 & 85 & 7 & 0.6 & 12 & 50 & 32 & 0.2 \\
\hline & diclofenac & $15307-86-5$ & 2 & 34 & 6 & 106 & 96 & 115 & 50 & 23 & 2 \\
\hline & ibuprofen & $15687-27-1$ & 0 & 34 & 0 & & & & 7 & 28 & \\
\hline & norflaxacin & 70458-96-7 & 4 & 13 & 31 & 2 & 0.7 & 4 & 150 & 30 & 0.02 \\
\hline & phenolphthalein & $77-09-8$ & 8 & 66 & 12 & 7 & 0.7 & 33 & & & \\
\hline & sulfamethoxazole & $723-46-6$ & 6 & 13 & 46 & 1 & 0.6 & 2 & 600 & 23 & 0.07 \\
\hline & trimethoprim & $738-70-5$ & 13 & 13 & 100 & 3 & 1 & 7 & & & \\
\hline & triclosan & $3380-34-5$ & 67 & 157 & 43 & 24 & 2 & 289 & 50 & 25 & 6 \\
\hline \multirow{10}{*}{ 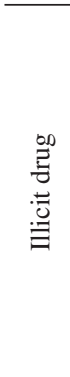 } & cocaine & $50-36-2$ & 27 & 51 & 53 & 10 & 2 & 62 & & & \\
\hline & benzoylecgonine & $509-09-5$ & 43 & 51 & 84 & 133 & 10 & 1019 & & & \\
\hline & morphine & $57-27-2$ & 0 & 18 & 0 & & & & & & \\
\hline & morphine-glucuronide & 20290-09-9 & 0 & 18 & 0 & & & & & & \\
\hline & 6-acetylmorphine & $2784-73-8$ & 0 & 18 & 0 & & & & & & \\
\hline & amphetamine & $300-62-9$ & 0 & 18 & 0 & & & & & & \\
\hline & methamphetamine & $537-46-2$ & 0 & 18 & 0 & & & & & & \\
\hline & 3,4-MDEA & $74341-78-9$ & 0 & 18 & 0 & & & & & & \\
\hline & 3,4-MDMA & $1797883-86-3$ & 0 & 18 & 0 & & & & & & \\
\hline & 3,4-MDA & 4764-17-4 & 0 & 18 & 0 & & & & & & \\
\hline \multirow{9}{*}{ 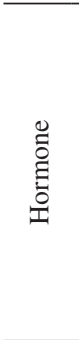 } & $17 \alpha$-ethinylestradiol & $57-63-6$ & 9 & 221 & 4 & 777 & 4 & 4390 & 0.03 & 23 & 146000 \\
\hline & $17 \beta$-estradiol & $50-28-2$ & 20 & 221 & 9 & 969 & 2 & 6806 & 0.4 & 23 & 17000 \\
\hline & diethylstilbestrol & $56-53-1$ & 0 & 155 & 0 & & & & & & \\
\hline & estriol & $50-27-1$ & 58 & 187 & 31 & 38 & 1 & 1398 & 60 & 33 & 23 \\
\hline & estrone & $53-16-7$ & 62 & 221 & 28 & 5 & 0.8 & 39 & 3.6 & 23 & 10 \\
\hline & levonorgestrel & $17489-40-6$ & 10 & 188 & 5 & 133 & 1 & 663 & & & \\
\hline & mestranol & $72-33-3$ & 0 & 153 & 0 & & & & & & \\
\hline & progesterone & $57-83-0$ & 4 & 191 & 2 & 73 & 2 & 195 & & & \\
\hline & testosterone & $58-22-0$ & 21 & 156 & 13 & 25 & 1 & 329 & 20 & 22 & 16 \\
\hline \multirow{8}{*}{ 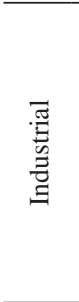 } & 4-n-nonylphenol & $104-40-5$ & 5 & 205 & 2 & 429 & 1 & 2018 & 140 & 11 & 14 \\
\hline & 4-n-octylphenol & $1806-26-4$ & 2 & 205 & 2 & 266 & 2 & 1029 & & & \\
\hline & benzylbutylphthalate & $85-68-7$ & 0 & 2 & 0 & & & & 270 & 34 & \\
\hline & bisphenol A & $80-05-7$ & 145 & 217 & 67 & 513 & 2 & 13016 & 240 & 23 & 54 \\
\hline & dibutylphthalate & $84-74-2$ & 34 & 36 & 94 & 8230 & 1300 & 33100 & & & \\
\hline & diethylphthalate & $84-66-2$ & 0 & 36 & 0 & & & & & & \\
\hline & dimethylphthalate & $131-11-3$ & 0 & 2 & 0 & & & & & & \\
\hline & dioctylphthalate & $117-81-7$ & 2 & 2 & 100 & 570 & 465 & 674 & & & \\
\hline
\end{tabular}

WQC: water quality criteria; MEC: maximum environmental concentrations; n: number of samples; 3,4-MDEA: 3,4-methylenedioxy- $N$-ethylamphetamine hydrochloride; 3,4-MDMA: 3,4-methylenedioxymethamphetamine; 3,4-MDA: 3,4-methylenedioxyamphetamine hydrochloride.

Nineteen substances were investigated in an intermediate number of samples, i.e., between 50 and 100. The vast majority of these substances were pesticides, in addition to cocaine, benzoylecgonine and phenolphthalein. Considering only the pesticides investigated in this group, carbendazim was the most frequently detected substance (90\% of samples), followed by imidacloprid (47\%), ametryn (38\%), trifloxystrobin (38\%), clomazone (29\%) and azoxystrobin (28\%). Cocaine and its most prevalent metabolite, benzoylecgonine, were detected in 53 and $84 \%$ of the samples, respectively. No other target illicit substance or its derivatives were detected.

Most of the pharmaceuticals were investigated in less than 50 samples, including diclofenac, acetylsalicylic acid, acetaminophen and ibuprofen, as well as 7 antibiotics were investigated in 13 samples. Among them, amoxicillin, trimethoprim and cephalexin were detected in all samples, followed by ciprofloxacin $(85 \%)$, sulfamethoxazole 


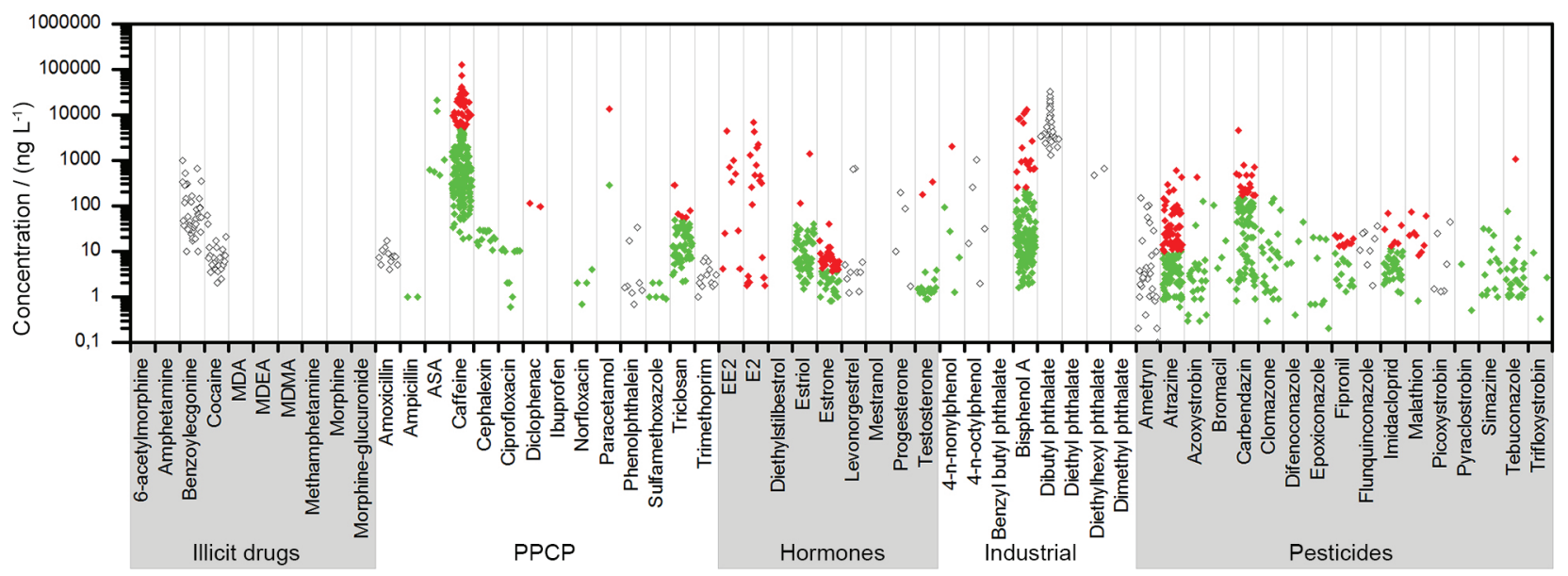

Figure 2. Concentrations of illicit drugs, pharmaceuticals and personal care products, hormones, industrial compounds and pesticides in surface water samples collected in São Paulo State between 2006 and 2015. Green represents the concentration below water quality criteria (WQC), red represents the concentrations higher than the WQC and grey the concentrations of compounds without WQC.

$(46 \%)$, norfloxacin $(31 \%)$, acetylsalicylic acid $(18 \%)$ and ampicillin (15\%).

Finally, other 6 substances commonly associated with their industrial origins, which are also notably found in consumer goods, were investigated, including bisphenol A that was quantified in 145 of the 217 samples in a wide range of concentrations, between 2 and $13016 \mathrm{ng} \mathrm{L}^{-1}$. Among these substances, dibutylphthalate was investigated in 36 samples and was found in 34 , corresponding to a frequency of detection $94 \%$. Dioctylphthalate was found in the two samples, but other phthalates have never been found. The occurrence data is described below and classified by compound class.

\section{Pesticides}

Pesticide contamination of surface waters has been well documented worldwide as it represents a major issue when aspects related to water quality and uses are concerned. In this study, a wide range of concentrations was noticed for pesticides (Figure 2) being the fungicide carbendazim, by far, the most frequent as well as the most abundant substance. Considering only positive data, the concentration of carbendazim varied from 0.8 to $4520 \mathrm{ng} \mathrm{L}^{-1}$, reflecting different characteristics of the sampling points. This broadspectrum fungicide is widely used in different crops and forests, but also as a household biocide. ${ }^{35,36}$ Palma et al. ${ }^{37}$ verified surface water contamination with carbendazim at levels of up to $1200 \mathrm{ng} \mathrm{L}^{-1}$ in an agricultural-forestry basin in Southern Chile. However, the authors could not explain the origin of contamination since neither rain or pesticide application were registered during the sampling period. Lower concentrations of carbendazim, in comparison to our data, were also observed by Masiá et al. ${ }^{38}$ in water samples of the Guadalquivir River Basin, an agriculture-based watershed in Spain. According to the authors, this fungicide presented maximum concentrations of $11 \mathrm{ng} \mathrm{L}^{-1}$, with a frequency of detection of $17 \%$. Besides the agriculture use, one can consider the contamination of urban waters due to carbendazim use as a household biocide. Burkhardt et al..$^{39}$ investigated the leaching of pesticides used in plants and building materials to sewer systems and concluded that, after the first flush, concentrations of the investigated substances, including carbendazim, exceeded the Swiss water quality standard. Chen et al. ${ }^{40}$ investigated different biocides in aquatic environments of a highly urbanized region in China and also concluded that domestic sewage was the dominant pollution source for most biocides.

Triazoles, also used as broad-spectrum fungicides, were the second most abundant group of pesticides. In this group, tebuconazole was found in $31 \%$ of the samples and presented an average concentration of $39 \mathrm{ng} \mathrm{L}^{-1}$. Other triazole fungicides presented average and maximum concentrations at the same order of magnitude. However, a maximum concentration of $1071 \mathrm{ng} \mathrm{L}^{-1}$ was noticed for tebuconazole in this work. Contamination of surface waters with tebuconazole by runoff from cropped areas is well documented, ${ }^{41,42}$ but this fungicide is also used as a household biocide making it also commonly found in wastewaters and, consequently, in urban affected surface waters. ${ }^{43,44} \mathrm{An}$ average concentration up to $35 \mathrm{ng} \mathrm{L}^{-1}$ were estimated by Gerónimo et al.${ }^{45}$ in Argentinean agricultural river basins, whereas concentrations up to $15 \mathrm{ng} \mathrm{L}^{-1}$ were reported by da Silva et al. ${ }^{46}$ investigating surface waters nearby rice crops in the southern region of Brazil.

Fungicides of the $\beta$-methoxyacrylates group were also investigated in this work and presented average concentrations varying from 3 to $13 \mathrm{ng} \mathrm{L}^{-1}$. The most abundant fungicide of this group was azoxystrobin, which 
presented a maximum concentration of $431 \mathrm{ng} \mathrm{L}^{-1}$. In the study carried out by Battaglin et al. ${ }^{47}$ azoxystrobin was the most frequently detected fungicide $(45 \%)$ in U.S. rivers with a maximum concentration of $1130 \mathrm{ng} \mathrm{L}^{-1}$. According to the authors, its widespread occurrence was associated with its increasing use in a variety of agricultural and nonagricultural settings in the United States.

Atrazine, the second most frequently detected pesticide in this work, presented a maximum concentration of $611 \mathrm{ng} \mathrm{L}^{-1}$. Although this triazine herbicide is included in several aquatic life standards, its presence in surface waters has an emerging concern due to possible endocrine disrupting effects at low concentrations. ${ }^{48}$ Since the occurrence of atrazine is commonly associated to agricultural activities, ${ }^{49,50}$ its concentrations are strongly dependent on the watershed characteristics. Steady concentrations around $500 \mathrm{ng} \mathrm{L}^{-1}$ has been noticed in the Mississipi River and its major tributaries during the past three decades suggesting that atrazine use in the area has not diminished..$^{51,52}$ Concentrations around $17 \mathrm{ng} \mathrm{L}^{-1}$ were detected by Moreno-González et al. ${ }^{53}$ in a seasonal investigation carried out in a Mediterranean coastal lagoon. Similar levels were also found by Masiá et $a l . .^{54}$ in the Guadalquivir River Basin, in Spain. Lower concentrations in European samples may be a consequence of atrazine banishment in the European Union..$^{55}$ Other studies carried out in Brazil have found concentrations similar to those of the present work. ${ }^{56,57}$ Other triazines were also investigated in this work, with emphasis to ametryn, which presented a maximum concentration of $148 \mathrm{ng} \mathrm{L}^{-1}$ in the investigated samples. The herbicides clomazone and bromacil were also quantified at similar concentrations, but the latter was detected only in $2 \%$ of the samples.

The insecticides imidacloprid, fipronil and malathion were also detected in the samples, being the former the most frequent in the samples. Average concentration for the insecticides varied between 10 and $26 \mathrm{ng} \mathrm{L}^{-1}$.

\section{Pharmaceuticals and personal care products}

A wide range of concentrations was observed for pharmaceuticals (Figure 2) with relatively high concentrations noticed for acetaminophen, acetylsalicylic acid and caffeine. Caffeine levels in this work varied from 19 to $127000 \mathrm{ng} \mathrm{L}^{-1}$, reflecting the differences between sampling points according to their anthropic impact. Kolpin et al. ${ }^{58}$ investigated more than 70 water samples collected upstream and downstream of selected urban areas from Iowa (USA) for caffeine analysis and other organic wastewater contaminants. Caffeine levels for low-flow streams were the highest amidst other flow conditions reaching a maximum of $294 \mathrm{ng} \mathrm{L}^{-1}$, i.e., almost 430 times lower than the maximum concentration reported in this work. Ide et al. ${ }^{59}$ investigated the presence of caffeine along the Iguaçu River, in Southern Brazil, and verified concentrations up to $5170 \mathrm{ng} \mathrm{L}^{-1}$ due to a large human influence in the upper part of the river.

Average concentrations around $6000 \mathrm{ng} \mathrm{L}^{-1}$ were noticed for acetylsalicylic acid and acetaminophen, two of the most consumed nonprescription pharmaceuticals in Brazil. Diclofenac was detected at an average concentration of $106 \mathrm{ng} \mathrm{L}^{-1}$, which is a little higher than the annual average environmental quality standard (AA EQS $=100 \mathrm{ng} \mathrm{L}^{-1}$ ) proposed by European Union. ${ }^{6}$ After a systematic literature review that included articles over the period from 1995 to 2015 about the occurrence of diclofenac in European surface waters, Tiedeken et al. ${ }^{6}$ concluded that in general the concentrations were below AA EQS. Besides the high levels accounted for acetylsalicylic acid and acetaminophen in surface waters from the region of São Paulo, it is important to mention that these pharmaceuticals were not frequently detected in the samples, probably due to changes in the quantification limits of the methods over the years. Hu et al. ${ }^{60}$ investigated the occurrence of 25 pharmaceuticals in a Chinese lake and observed average concentrations varying between 45 and $58 \mathrm{ng} \mathrm{L}^{-1}$, depending on the season of the sampling. Tewari et al. ${ }^{61}$ reported acetaminophen concentrations from 44 to $435 \mathrm{ng} \mathrm{L}^{-1}$ in six discharge canals of the Chao Phraya River, in Thailand as well as concentrations up to $70 \mathrm{ng} \mathrm{L}^{-1}$ in the receiving waters. The authors also showed that acetylsalicylic acid presented the highest concentration in the surface water samples ranging between 23 and $1100 \mathrm{ng} \mathrm{L}^{-1}{ }^{61}$

An average concentration of $24 \mathrm{ng} \mathrm{L}^{-1}$ was depicted for triclosan in the positive samples, with minimum and maximum levels of 2 and $289 \mathrm{ng} \mathrm{L}^{-1}$. Bedoux et al. ${ }^{62}$ reviewed the occurrence of triclosan and its by-products in environmental samples revealing that concentrations worldwide are lower than those reported in this work. However, similar maximum concentrations were found in surface waters from Spain, ${ }^{63}$ Costa Rica ${ }^{64}$ and Brazil. ${ }^{65}$ Higher maximum levels of triclosan were observed by dos Santos et al. ${ }^{66}$ which investigated different rivers form the upper Iguaçu River Basin, in Brazil. Concentrations up to $415 \mathrm{ng} \mathrm{L}^{-1}$ were attributed to aspects such as direct raw sewage discharges into receiving waters, illegal sewer connections into pluvial drainage systems and inefficient removal at sewage treatment plants. ${ }^{66}$

\section{Illicit drugs}

Considering the illicit drug class, average concentrations of cocaine and benzoylecgonine were 10 and $133 \mathrm{ng} \mathrm{L}^{-1}$, 
respectively. The latter is commonly found at higher levels in environmental matrices due to its higher stability in aqueous samples. ${ }^{67}$ Also, after the drug use, a higher proportion of benzoylecgonine is excreted in comparison with the unaltered drug. ${ }^{68}$ Maximum concentrations of 62 and $1019 \mathrm{ng} \mathrm{L}^{-1}$ were also portrayed in Table 1 for cocaine and its metabolite, respectively. Concentrations in the investigated area were similar to those reported in countries such as Italy, ${ }^{69} \mathrm{UK}^{70}$ and Spain. ${ }^{71}$ Concentrations ranging from 1.1 to $115 \mathrm{ng} \mathrm{L}^{-1}$ for cocaine and from 2.3 to $520 \mathrm{ng} \mathrm{L}^{-1}$ for benzoylecgonine were reported in samples collected across Belgium. ${ }^{72}$ In Brazil, Thomas et al..$^{73}$ investigated selected licit and illicit drugs in the urban streams of Manaus, in the Brazilian Amazon, and reported concentrations up to 5896 and $3582 \mathrm{ng} \mathrm{L}^{-1}$ for cocaine and benzoylecgonine, respectively. The authors verified that concentrations of both contaminants increased downstream of the urban region suggesting a continuous input along the entire length of the stream probably through raw sewage inputs.

\section{Hormones}

Hormones were detected in a wide range of concentrations as can be seen in Figure 2. Higher concentrations were noticed for the endogenous estrogen $17 \beta$-estradiol (average of $969 \mathrm{ng} \mathrm{L^{-1 }}$ ), followed by the synthetic contraceptive $17 \alpha$-ethynylestradiol (average of $777 \mathrm{ng} \mathrm{L}^{-1}$ ). Despite their relatively high concentrations in comparison with the other investigated hormones, they were not frequently detected in the samples probably due to limitations of the quantification methods. On the other hand, the concentrations exceeded AA EQS values proposed by EU for these compounds $\left(0.04 \mathrm{ng} \mathrm{L}^{-1}\right.$ for $17 \beta$-estradiol and $0.035 \mathrm{ng} \mathrm{L}^{-1}$ for $17 \alpha$-ethynylestradiol). ${ }^{6}$ According to Tiedeken et al. ${ }^{6}$ the concentrations of $17 \beta$-estradiol and $17 \alpha$-ethynylestradiol in European surface water samples are typically below 50 and $10 \mathrm{ng} \mathrm{L}^{-1}$, respectively. Hormones such as estriol and estrone were more frequently detected, but at lower average concentrations ( 5 to $38 \mathrm{ng} \mathrm{L}^{-1}$ ). Levonorgestrel, other synthetic estrogen used as a contraceptive, was found at relatively high concentrations, i.e., from 1 to $663 \mathrm{ng} \mathrm{L}{ }^{-1}$. Quadra et al. ${ }^{74}$ evidenced that hormone concentrations in Brazilian waters are significantly higher in comparison to data collected worldwide. In addition, the authors concluded that hormones were more frequently studied in the environment probably due to their potential impact on humans. However, it is important to point out that hormones are also potentially harmful to the aquatic biota, which justifies the large number of reports involving this class of emerging contaminants. Torres et al..$^{75}$ investigated the presence of hormones in the Piracicaba River, Brazil, and observed highest levels for $17 \alpha$-ethynylestradiol and $17 \beta$-estradiol, in accordance with our results. Maximum hormone concentrations in Piracicaba River were assigned for $17 \alpha$-ethinylestradiol (194 $\mathrm{ng} \mathrm{\textrm {L } ^ { - 1 }}$ ), followed by $17 \beta$-estradiol (137 $\mathrm{ng} \mathrm{L}^{-1}$ ), estriol (90 ng $\left.\mathrm{L}^{-1}\right)$, estrone (28 $\mathrm{ng} \mathrm{L}^{-1}$ ), and progesterone (26 ng L ${ }^{-1}$ ). In water sources from the metropolitan area of Belo Horizonte, Brazil, natural and synthetic estrogens were detected in $15 \%$ of the samples and always at low concentrations, from 2 to $54 \mathrm{ng} \mathrm{\textrm {L } ^ { - 1 }}{ }^{76}$ In the Jaboticabal Region, in Brazil, Lopes et al. ${ }^{77}$ reported $17 \beta$-estradiol concentrations ranging from 16 to $30.6 \mathrm{ng} \mathrm{\textrm {L } ^ { - 1 }}$ in water samples from the Rico Creek only at the dry season.

\section{Industrial compounds}

Although six phthalates were considered in this work, only two were frequently investigated in surface water samples, i.e., diethylphthalate (DEP) and dibutyl phthalate (DBP), but only the latter was frequently detected. Dibutylphthalate levels ranged between 1.3 and $33.1 \mu \mathrm{g} \mathrm{L}^{-1}$, being one of the most abundant substances together with the non-prescribed pharmaceuticals caffeine, acetylsalicylic acid and acetaminophen. The occurrence of three phthalates was investigated in German surface water samples by Fromme et al..$^{78}$ that shows DBP was found in minor concentrations in comparison with butylbenzylphthalate (BBP) and di(2-ethylhexyl)phthalate (DEHP), ranging

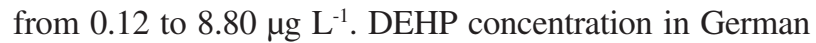
waters varied between 0.33 to $97.8 \mu \mathrm{g} \mathrm{L}^{-1}$ and it was mainly influenced by water runoff from dumps. In the present work DEHP was investigated only in two samples being always present at an average concentration of $0.465 \mu \mathrm{g} \mathrm{L}^{-1}$. Higher concentrations of DBP, in comparison with other phthalates, were also observed elsewhere. In rivers samples from Manchester, UK, Fatoki and Vernon ${ }^{79}$ reported concentrations of DBP varying from 12.1 to $33.5 \mu \mathrm{g} \mathrm{L}{ }^{-1}$, while Vitali et al. ${ }^{80}$ observed DBP concentrations up to $31.2 \mu \mathrm{g} \mathrm{\textrm {L } ^ { - 1 }}$ in surface water samples from the Rieti Basin in Italy.

Bisphenol A (BPA) levels in the present study varied between 2 to $13016 \mathrm{ng} \mathrm{L}^{-1}$ in the surface water samples, with an average concentration of $513 \mathrm{ng} \mathrm{L}^{-1}$. A relatively high concentration of BPA was also reported by Jin et al. ${ }^{81}$ in the Haihe River estuary, in China. The authors attributed an unusual concentration of $8.3 \mu \mathrm{g} \mathrm{L}^{-1}$ to a sewage outlet nearby the sampling point. ${ }^{81}$ Kolpin et al. ${ }^{58}$ observed an average BPA concentration of $740 \mathrm{ng} \mathrm{L}^{-1}$ for low flow U.S. streams, while at high flow conditions this contaminant was not detected. Santhi et al. ${ }^{82}$ detected BPA in $93 \%$ of the investigated surface waters from the Langat River basin, in Malaysia. Concentrations up to $215 \mathrm{ng} \mathrm{L}^{-1}$ were reported in samples used as potable water, while six fold higher levels were detected in samples collected nearby industrial and 
sewage treatment plant outlets. ${ }^{82}$ Huang et al. ${ }^{83}$ reviewed the levels of BPA in water samples from China in comparison with other countries and concluded that concentrations are much higher in cities located at highly developed industrial and commercial regions. In Brazil, Moreira et al ${ }^{84}$ reported the presence of BPA in all surface water samples from das Velhas River with concentrations varying from 8.6 to $168 \mathrm{ng} \mathrm{L}^{-1}$. In water samples from the upper Iguaçu River, in Brazil, Froehner et al. ${ }^{85}$ reported BPA levels ranging between 620 to $12610 \mathrm{ng} \mathrm{L}^{-1}$, i.e., very close to the results collected in this work. The authors concluded that the highest BPA levels were influenced by industrial and densely populated areas nearby the sampling points, which present a history of pollution by both domestic and industrial sewage inputs.

\section{Drinking water}

Two hundred and eighty-nine (289) samples of drinking water were analyzed by the group from 2007 to 2015 . The number of samples analyzed, the frequency of positive samples and the concentration of each compound are presented in Table 2 and in the SI section. Figure 3 shows a plot representation of concentrations and the preliminary risk assessment.

Table 2. Frequency of positive samples, concentration of the emerging compounds analyzed in drinking waters, and drinking water criteria (WQC) found in the literature. Risk quotients were calculated by dividing the maximum environmental concentration (MEC) by the most restrictive WQC

\begin{tabular}{|c|c|c|c|c|c|c|c|c|c|c|c|}
\hline Class & Compound & CAS number & $\begin{array}{l}\text { Positive } \\
\text { samples }\end{array}$ & $\mathrm{n}$ & $\begin{array}{c}\text { Frequency / } \\
\%\end{array}$ & $\begin{array}{l}\text { Mean / } \\
\left(n g L^{-1}\right)\end{array}$ & $\begin{array}{l}\text { Min. / } \\
\left(\operatorname{ng~L}^{-1}\right)\end{array}$ & $\begin{array}{c}\text { Max. } \\
(\mathrm{MEC}) / \\
\left(\mathrm{ng} \mathrm{L}^{-1}\right)\end{array}$ & $\begin{array}{l}\text { WQC / } \\
\left(n g L^{-1}\right)\end{array}$ & Reference & $\begin{array}{c}\text { Risk } \\
\text { quotient }\end{array}$ \\
\hline \multirow{17}{*}{$\begin{array}{l}\frac{0}{0} \\
\cdot 0 \\
0 \\
0 \\
0\end{array}$} & ametryn & $834-12-8$ & 0 & 25 & 0 & & & & 400000 & 13 & \\
\hline & atrazine & $1912-24-9$ & 130 & 179 & 73 & 36 & 1 & 687 & 2000 & 86 & $3 \times 10^{-1}$ \\
\hline & azoxystrobin & $131860-33-8$ & 3 & 31 & 10 & 1 & 1 & 2 & 100000 & 86 & $2 \times 10^{-5}$ \\
\hline & bromacil & $314-40-9$ & 1 & 31 & 3 & 0.7 & 0.7 & 0.7 & 400000 & 87 & $2 \times 10^{-6}$ \\
\hline & carbendazim & $10605-21-7$ & 3 & 33 & 9 & 9 & 2 & 15 & 120000 & 13 & $1 \times 10^{-4}$ \\
\hline & clomazone & 81777-89-1 & 10 & 27 & 37 & 28 & 0.6 & 158 & 200000 & 86 & $8 \times 10^{-4}$ \\
\hline & difenoconazole & $119446-68-3$ & 1 & 31 & 3 & 2 & 2 & 2 & 3600000 & 86 & $5 \times 10^{-7}$ \\
\hline & epoxiconazole & $133855-98-8$ & 1 & 31 & 3 & 14 & 14 & 14 & 20000 & 86 & $7 \times 10^{-4}$ \\
\hline & fipronil & $120068-37-3$ & 7 & 20 & 35 & 5 & 1 & 13 & 1000 & 86 & $1 \times 10^{-2}$ \\
\hline & flunquinconazole & $136426-54-5$ & 2 & 31 & 6 & 12 & 6 & 18 & 300000 & 86 & $6 \times 10^{-5}$ \\
\hline & imidacloprid & $138261-41-3$ & 19 & 31 & 61 & 11 & 3 & 63 & 300000 & 86 & $2 \times 10^{-4}$ \\
\hline & malathion & $121-75-5$ & 6 & 26 & 23 & 23 & 5 & 70 & 1800000 & 86 & $4 \times 10^{-4}$ \\
\hline & picoxystrobin & $117428-22-5$ & 0 & 31 & 0 & & & & 260000 & 86 & \\
\hline & pyraclostrobin & $175013-18-0$ & 0 & 31 & 0 & & & & 240000 & 86 & \\
\hline & simazine & $122-34-9$ & 8 & 25 & 32 & 10 & 4 & 40 & 2000 & 87 & $2 \times 10^{-2}$ \\
\hline & tebuconazole & $107534-96-3$ & 7 & 30 & 23 & 10 & 2 & 42 & 180000 & 86 & $2 \times 10^{-4}$ \\
\hline & trifloxystrobin & $141517-21-7$ & 0 & 31 & 0 & & & & 180000 & 86 & \\
\hline \multirow{3}{*}{$\frac{0}{2}$} & caffeine & $58-08-2$ & 207 & 231 & 90 & 548 & 2 & 5845 & & & \\
\hline & phenolphthalein & $77-09-8$ & 8 & 123 & 7 & 22 & 6 & 92 & & & \\
\hline & triclosan & $3380-34-5$ & 36 & 186 & 19 & 15 & 2 & 37 & 2000000 & 13 & $2 \times 10^{-5}$ \\
\hline \multirow{2}{*}{$\stackrel{0}{.} \stackrel{0}{\Xi}$} & cocaine & $50-36-2$ & 3 & 9 & 33 & 14 & 6 & 22 & & & \\
\hline & benzoylecgonine & $509-09-5$ & 7 & 9 & 78 & 212 & 63 & 652 & & & \\
\hline \multirow{9}{*}{$\begin{array}{l}\stackrel{0}{0} \\
\stackrel{0}{E} \\
\stackrel{0}{0} \\
\stackrel{1}{1}\end{array}$} & $17 \alpha$-ethinylestradiol & $57-63-6$ & 1 & 175 & 1 & 32 & 32 & 32 & & & \\
\hline & $17 \beta$-estradiol & $50-28-2$ & 3 & 175 & 2 & 25 & 18 & 35 & 3.8 & 88 & 9 \\
\hline & diethylstilbestrol & $56-53-1$ & 0 & 122 & 0 & & & & & & \\
\hline & estriol & $50-27-1$ & 3 & 167 & 2 & 44 & 0.4 & 125 & & & \\
\hline & estrone & $53-16-7$ & 4 & 175 & 2 & 11 & 0.6 & 20 & & & \\
\hline & levonorgestrel & $17489-40-6$ & 1 & 112 & 1 & 4 & 4 & 4 & 724 & 88 & $5 \times 10^{-3}$ \\
\hline & mestranol & $72-33-3$ & 0 & 106 & 0 & & & & & & \\
\hline & progesterone & $57-83-0$ & 1 & 137 & 1 & 24 & 24 & 24 & 333 & 88 & $7 \times 10^{-2}$ \\
\hline & testosterone & $58-22-0$ & 8 & 215 & 4 & 3 & 2 & 5 & 11 & 88 & $4 \times 10^{-1}$ \\
\hline \multirow{8}{*}{ 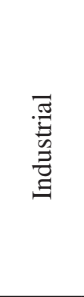 } & 4-n-nonylphenol & $104-40-5$ & 3 & 189 & 2 & 114 & 88 & 130 & & & \\
\hline & 4-n-octylphenol & $1806-26-4$ & 8 & 168 & 5 & 225 & 0.3 & 1137 & & & \\
\hline & benzylbutylphthalate & $85-68-7$ & 0 & 16 & 0 & & & & & & \\
\hline & bisphenol A & $80-05-7$ & 50 & 258 & 19 & 23 & 1 & 178 & & & \\
\hline & dibutylphthalate & $84-74-2$ & 16 & 16 & 100 & 6943 & 3427 & 11585 & 600000 & 13 & $2 \times 10^{-2}$ \\
\hline & diethylphthalate & $84-66-2$ & 0 & 16 & 0 & & & & & & \\
\hline & dimethylphthalate & $131-11-3$ & 0 & 16 & 0 & & & & & & \\
\hline & dioctylphthalate & $117-81-7$ & 12 & 16 & 75 & 272 & 121 & 475 & & & \\
\hline
\end{tabular}

$\mathrm{n}$ : number of samples; PPCP: pharmaceutical and personal care product. 
The 39 target compounds investigated in drinking water included 17 pesticides, 9 hormones, 8 industrial compounds, caffeine, phenolphthalein, triclosan, cocaine and benzoylecgonine. Bisphenol A was the most frequently investigated contaminant (258 samples) followed by caffeine (231), testosterone (215), 4- $n$-nonylphenol (189), triclosan (186) and atrazine (179).

The most prevalent substance among the most frequently investigated was caffeine $(90 \%)$, atrazine $(73 \%)$, BPA (19\%) and triclosan (19\%). All four substances, except for atrazine, appeared in the list of selected chemicals proposed by Glassmeyer et al. ${ }^{89}$ that are useful as tracers of human wastewater. In fact, the presence of caffeine in Brazilian waters are commonly associated with sewage contamination, as previously reported elsewhere. ${ }^{90}$

All hormones were investigated in more than 100 samples, being the most investigated class of emerging contaminants. Although their frequency of detection varied from zero to $4 \%$.

Pesticides were investigated in fewer samples, except for atrazine, and presented high to intermediate frequencies of detection, being the herbicide atrazine the most frequent (73\%), followed by imidacloprid (61\%), clomazone (37\%), fipronil (35\%), simazine (32\%), tebuconazole (23\%) and malathion $(23 \%)$. Although phthalates were investigated in only 16 samples, two substances of this class presented a high frequency of detection: dibutylphthalate (100\%) and dioctylphthalate (75\%). Cocaine was detected in $33 \%$ of the samples while benzoylecgonine, in $78 \%$.

\section{Pesticides}

Few data are available in the literature about the presence of pesticides in drinking waters. Average and maximum atrazine concentrations in this work were of 36 and
$687 \mathrm{ng} \mathrm{L}^{-1}$. In Brazil, lower concentrations, between 2.0 and $24 \mathrm{ng} \mathrm{L}^{-1}$, were previously reported in drinking water samples from 16 capitals. ${ }^{19}$ Sodré et al. ${ }^{91}$ reported concentrations ranging from 2 to $3.3 \mathrm{ng} \mathrm{L}^{-1}$ in all samples collected from the Descoberto production system in the Brazilian Federal District. Median and maximum concentrations around 50 and $930 \mathrm{ng} \mathrm{L}^{-1}$ were observed in finished and distribution U.S. drinking waters by Benotti et al..$^{92}$ while Padhye et al.$^{93}$ noticed a median concentration of $15 \mathrm{ng} \mathrm{L}^{-1}$ in finished and drinking waters from a major U.S. urban region. Imidacloprid was detected in concentrations between 3 and $63 \mathrm{ng} \mathrm{L}^{-1}$ in this work and similar concentrations were detected in tap waters from Iowa City in the United States. ${ }^{94}$ Otherwise, the average concentration of fipronil detected in this work was $5 \mathrm{ng} \mathrm{L}^{-1}$, which is less than the average concentration (160 ng L ${ }^{-1}$ ) found in Vietnam. ${ }^{95}$

\section{Pharmaceuticals and personal care products}

Recently, Machado et al..$^{19}$ investigated the presence of caffeine in drinking waters collected in different Brazilian capitals and showed higher average levels in samples collected in the city of Porto Alegre (1211 ng L-1), probably due to cultural peculiarities related to the consumption of yerba mate (Ilex paraguariensis) on a daily basis. The city of São Paulo was ranked in the top five capitals with an average concentration of $121 \mathrm{ng} \mathrm{L}^{-1}$.

Triclosan was found at concentrations ranging from 2 to $37 \mathrm{ng} \mathrm{L}^{-1}$ in this work. Yavuz et al..$^{96}$ studied the levels of biocides in source and drinking water systems of Ankara, Turkey and noticed that the concentration of triclosan in all samples were below the limit of quantification of $0.87 \mathrm{ng} \mathrm{L}^{-1}$. Benotti et al..$^{92}$ investigated finished and distribution waters from 19 U.S. water utilities and found triclosan in only one finished water sample at a

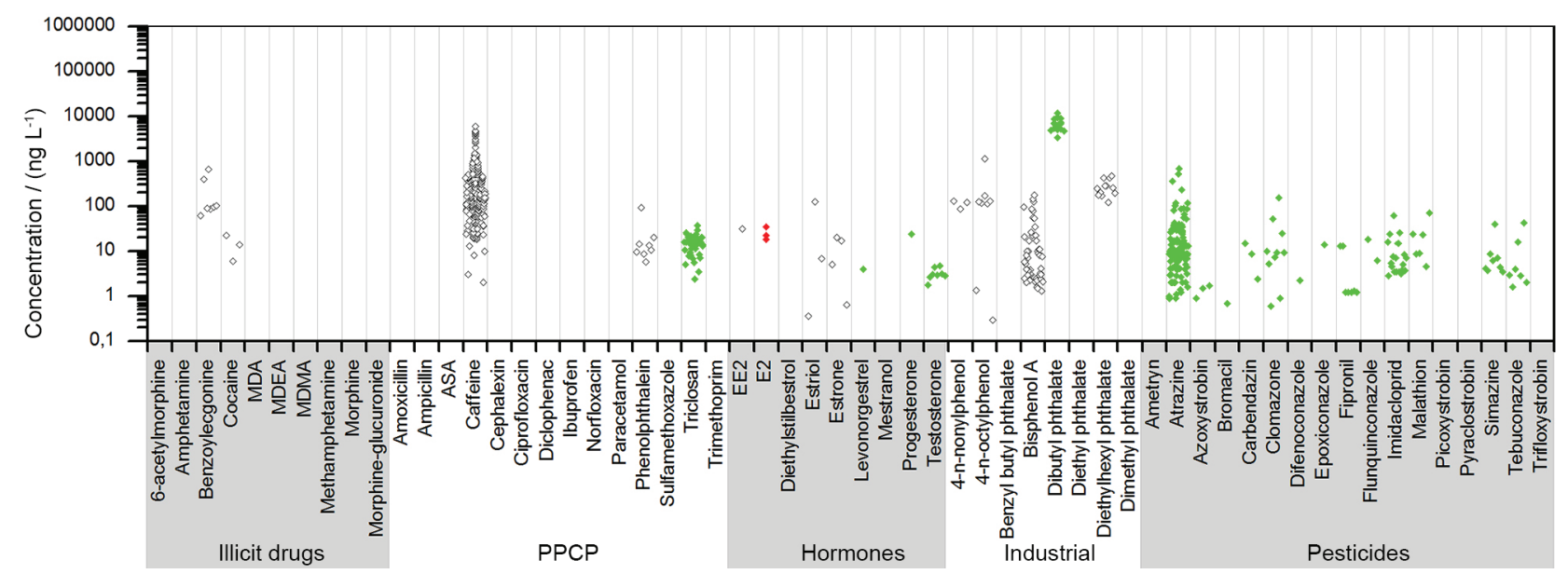

Figure 3. Concentrations of illicit drugs, pharmaceuticals and personal care products (PPCP), hormones, industrial compounds and pesticides in drinking water samples collected in São Paulo State from 2007 to 2015. Green represents the concentration below water quality criteria (WQC), red represents the concentrations higher than the WQC and grey the concentrations of compounds without WQC. 
concentration of $1.2 \mathrm{ng} \mathrm{L}^{-1}$. Concentrations below $1 \mathrm{ng} \mathrm{L}^{-1}$ were reported by Servos et al. ${ }^{97}$ investigating finished water produce from different types of source waters in the region of Ontario, Canada. In the nationwide survey carried out in Brazil, triclosan was detected in only one sample collected in the city of Porto Alegre at a concentration of $10 \mathrm{ng} \mathrm{L}^{-1} .{ }^{19}$ A triclosan concentration as high as those depicted in this work was found by Padhye et al. ${ }^{93}$ investigating the removal of emerging contaminants in a drinking water supplier in the Southeast United States. The authors reported a frequency of detection of $63 \%$ for triclosan with median and maximum concentrations of 1.4 and $59.6 \mathrm{ng} \mathrm{L}^{-1}$.

\section{Illicit drugs}

Illicit drugs were investigated only in few samples. Average concentration for benzoylecognine was higher (212 $\left.\mathrm{ng} \mathrm{L}^{-1}\right)$ in comparison to cocaine $\left(14 \mathrm{ng} \mathrm{L}^{-1}\right)$. HuertaFontela et al. ${ }^{98}$ showed that benzoylecgonine is persistent during conventional drinking water treatment, while cocaine is efficiently removed after post-chlorination and filtration in granulated activated carbon. Boleda et al..$^{99}$ investigated the presence of drugs of abuse in tap waters collected in Europe, Japan and Latin America and reported lower values for the two cocaine compounds in comparison to our data. According to the authors, an average concentration of $0.4 \mathrm{ng} \mathrm{L}^{-1}$ was accounted for both compounds in samples collected in Spanish tap waters, while concentrations up to 0.6 and $4.5 \mathrm{ng} \mathrm{L}^{-1}$ were observed for cocaine and benzoylecgonine, respectively, in Latin American countries. ${ }^{99}$

\section{Hormones}

Concentrations of hormones up to $125,35,32,24$ and $20 \mathrm{ng} \mathrm{L}^{-1}$ were observed for estriol, 17 $\beta$-estradiol, $17 \alpha$-ethinylestradiol, progesterone and estrone, respectively. These values are considered high in comparison with data reported elsewhere. Kuster et al. ${ }^{100}$ verified that all drinking water samples investigated from the Llobregat River Basin (Barcelona, Spain) were free of estrogens with the exception of one sample where estriol was found at $11.6 \mathrm{ng} \mathrm{L}^{-1}$. In German, it was reported maximum concentrations of estrone, $17 \alpha$-estradiol, $17 \beta$-estradiol and $17 \alpha$-ethinylestradiol varying from 0.3 to $2.1 \mathrm{ng} \mathrm{L}^{-1} .{ }^{101}$ Benotti et al. ${ }^{92}$ investigated five hormones in U.S. drinking waters being all results presented as below the maximum residue limit, except for progesterone that was found in one finished water samples at a concentration of $0.57 \mathrm{ng} \mathrm{L}^{-1}$. Similar result was reported by Cai et al. ${ }^{102}$ investigating $17 \beta$-estradiol in drinking waters from Beijing, China. In Brazil, hormones were investigated in finished waters from different cities with wide range concentrations $\left(0.3-2170 \mathrm{ng} \mathrm{L}^{-1}\right){ }^{92}$

\section{Industrial compounds}

The presence of BPA in Brazilian drinking waters has been also associated with the contamination of source waters by sewage discharges. Despite its industrial origins, BPA is part of our life style and it is still being used in a variety of manufactured consumer goods in Brazil. In this work, concentrations up to $178 \mathrm{ng} \mathrm{L}^{-1}$ were noticed in the investigated samples, with an average level of $23 \mathrm{ng} \mathrm{L}^{-1}$. Kuch and Ballschmiter ${ }^{101}$ found BPA in drinking water samples from Southern Germany in concentrations ranging from 0.3 to $2 \mathrm{ng} \mathrm{L}^{-1}$. Concentrations ranging from 3.5 to $59.8 \mathrm{ng} \mathrm{L}^{-1}$ were reported by Santhi et al. ${ }^{82}$ in tap water samples from the region of Kuala Lumpur, in Malaysia. The authors also suggested that higher concentrations were probably caused by polyvinyl chloride (PVC) fittings and filter devices connected to the taps ${ }^{82}$ Bisphenol A concentrations up to $128 \mathrm{ng} \mathrm{L}^{-1}$, thus similar to our results, were also found in finished water samples from 62 drinking water treatment plants in 31 major cities across China. ${ }^{103}$

Considering the alkylphenols 4- $n$-nonylphenol and 4-n-octylphenol, average concentrations of 114 and $225 \mathrm{ng} \mathrm{L}^{-1}$, respectively, were observed, although a considerably high concentration of 4- $n$-octylphenol (1137 $\mathrm{ng} \mathrm{L}^{-1}$ ) was also noticed. Kuch and Ballschmiter ${ }^{101}$ also found alkylphenols in drinking waters from Germany, but the maximum concentrations were 4.9 and $16 \mathrm{ng} \mathrm{L}^{-1}$ for 4-tert-octylphenol and 4-n-nonylphenol, respectively. For the latter substance, Shao et al. ${ }^{104}$ reported concentrations varying from 10 to $2700 \mathrm{ng} \mathrm{L}^{-1}$ in drinking water samples collected in the area of Chongqing (China).

Dioctylphthalate presented the highest levels among the investigated contaminants with an average concentration of around $7 \mu \mathrm{g} \mathrm{L} \mathrm{L}^{-1}$. Casajuana and Lacorte ${ }^{105}$ evaluated the release of phthalic esters in drinking water reporting dibutylphthalate concentrations varying between 0.016 and $0.032 \mu \mathrm{g} \mathrm{L}^{-1}$ in distribution waters collected from public fountains in the Vallbs area (Catalonia, Spain). In mineral waters bottled in polyethylene, the authors verified slightly higher concentrations when compared to the distribution of water samples. ${ }^{105}$ Serôdio and Nogueira ${ }^{106}$ showed that dibutylphthalate was the most abundant phthalate whether in tap $\left(0.52 \mu \mathrm{g} \mathrm{L}^{-1}\right)$ or in bottled mineral $\left(0.35 \mu \mathrm{g} \mathrm{L}^{-1}\right)$ waters from Lisbon, Portugal. An average concentration of $2.73 \mu \mathrm{g} \mathrm{L}{ }^{-1}$, thus similar to our results, were reported by Loraine and Pettigrove ${ }^{107}$ investigating emerging contaminants in finished drinking water in San Diego (USA).

\section{Groundwaters}

The results collected for the analyses of the thirty-three groundwater samples are presented in Table 3. The samples 
Table 3. Frequency of positive samples and concentrations of the emerging contaminants analyzed in 33 groundwater samples collected in the state of São Paulo from 2009 to 2012

\begin{tabular}{|c|c|c|c|c|c|c|}
\hline Compound & Positive samples & $\mathrm{n}$ & Frequency / \% & Mean / $\left(\mathrm{ng} \mathrm{L}^{-1}\right)$ & Min. / (ng L-1) & Max. / (ng L $\left.{ }^{-1}\right)$ \\
\hline Caffeine & 17 & 31 & 55 & 14 & 2 & 53 \\
\hline Phenolphthalein & 0 & 7 & 0 & & & \\
\hline Estrone & 1 & 32 & 3 & 5 & 5 & 5 \\
\hline $17 \beta$-Estradiol & 0 & 32 & 0 & & & \\
\hline Estriol & 0 & 32 & 0 & & & \\
\hline Progesterone & 1 & 29 & 3 & 10 & 10 & 10 \\
\hline Testosterone & 2 & 29 & 6 & 35 & 34 & 36 \\
\hline $17 \alpha$-Ethynylestradiol & 0 & 32 & 0 & & & \\
\hline Mestranol & 0 & 29 & 0 & & & \\
\hline Levonorgestrel & 0 & 29 & 0 & & & \\
\hline Diethylstilbestrol & 0 & 29 & 0 & & & \\
\hline Triclosan & 3 & 29 & 10 & 79 & 22 & 284 \\
\hline Bisphenol A & 16 & 32 & 50 & 50 & 2 & 643 \\
\hline 4- $n$-Octylphenol & 0 & 32 & 0 & & & \\
\hline 4-n-Nonylphenol & 0 & 32 & 0 & & & \\
\hline Atrazine & 6 & 7 & 86 & 3 & 2 & 5 \\
\hline
\end{tabular}

$\mathrm{n}$ : number of samples.

were collected in Guarani Aquifer ( $\mathrm{n}=12)$, Bauru Aquifer $(n=14)$ and in wells used to public supply in the rural area of the city of Campinas (SP) $(n=7)$.

The most prevalent contaminant was the herbicide atrazine detected in $86 \%$ of samples, followed by caffeine (55\%) and bisphenol A (50\%). Triclosan, estrone, testosterone and progesterone were detected in less than $10 \%$ of the samples. This is of great concern since most of the samples were collected in deep wells (> 300 meter), in which anthropic contamination is expected to be more controlled.

Pesticides are the most investigated contaminants in groundwater samples around the world due to the potential of contamination by percolation through agricultural soils located nearby aquifer recharge areas. Dujaković et al. ${ }^{108}$ investigated 14 pesticides, including atrazine, in 6 groundwater samples from Belgrade, Serbia, and reported results below the limit of detection (1.5 $\left.\mathrm{ng} \mathrm{L}^{-1}\right)$. Schipper et al. ${ }^{109}$ detected pesticides in $27 \%$ of the 771 groundwater samples from The Netherlands.

Loos et al. ${ }^{110}$ investigated the occurrence of organic pollutants in 164 ground water samples collected from 23 European countries. Caffeine was quantified in $83 \%$ of the samples with a maximum concentration of $189 \mathrm{ng} \mathrm{L}^{-1}$, thus being higher than the maximum concentrations reported in this work $\left(53 \mathrm{ng} \mathrm{L}^{-1}\right)$. In addition, although atrazine presented a high frequency detection, its concentrations varied between 2 and $5 \mathrm{ng} \mathrm{L}^{-1}$, which were about 250 times lower that the levels found by Loos et al. ${ }^{110}$ Bisphenol A presented the highest concentration in this work (643 $\left.\mathrm{ng} \mathrm{L}^{-1}\right)$, but also lower than maximum levels found in Europe (2300 ng L $\left.{ }^{-1}\right){ }^{110}$
Rabiet et al. ${ }^{111}$ detected caffeine concentrations between 1.5 and $23 \mathrm{ng} \mathrm{L}^{-1}$ as well as other pharmaceuticals in wells used to supply drinking water to the Hérault watershed located in the south of France. Caffeine was also detected with other pharmaceuticals in groundwater samples from a drinking-water supply system located in the state of California (USA) in concentrations varying between 170 and $290 \mathrm{ng} \mathrm{L}^{-1} .{ }^{112}$ Despite the relatively high concentrations of caffeine in the samples, the authors found this contaminant only in $1 \%$ of the 1231 samples investigated.

It is known that the evaluation of the risks related to the presence of emerging contaminants in groundwater requires a more detailed study on the presence of metabolites ${ }^{113}$ and the effects caused by the mixture of several compounds, which confers greater complexity in the choice of contaminants that must be monitored, but provides a more realistic scenario of the contamination stage.

\section{Preliminary risk assessment}

The preliminary risk assessment is shown in Figures 2 and 3 by colors in the plot representations. Green represents the concentrations below WQC (risk quocient smaller than 1), red represents the concentrations higher than the WQC (risk quocient greater than 1) and in grey are the compounds for which no WQC was found in the literature.

Potential risk for aquatic life were identified for 3 pharmaceuticals (paracetamol, caffeine and diclofenac), 5 hormones (estriol, estrone, 17 $\beta$-estradiol, $17 \alpha$-ethynylestradiol and testosterone), triclosan, 2 industrial 
compounds (4-n-nonylphenol and bisphenol A) and 7 pesticides (atrazine, azoxystrobin, carbendazim, fipronil, imidacloprid, malathion and tebuconazole) (Figure 2).

As no WQC were found, we used Binelli et al. ${ }^{114}$ findings as reference for illicit drugs and their main active metabolites. They showed that zebra mussels exposed to 0.5 and $1.0 \mu \mathrm{g} \mathrm{L}^{-1}$ of benzoylecgonine induced changes in some proteins of gill cells that are crucial for the overall metabolism. The concentrations found in our study are greater than those values, therefore, representing a possible risk to the biota. ${ }^{114}$

From the 39 substances analyzed in drinking water samples, drinking water criteria were available for 22 (Table 2). For pesticides, the quocient ranged from $10^{-2}$ to $10^{-7}$, therefore, no adverse effects are expected at the concentrations found, except for atrazine, which presented a risk quotient of 0.3 indicating some level of concern. Only for $17 \beta$-estradiol the risk quotient was higher than 1 , although the detection frequency was only $2 \%$ (Table 2, Figure 3 ).

Considering the number of groundwater samples analyzed in this study was limited to 33 , the data are not representative for risk assessment, but the concentrations of testosterone, bisphenol A and triclosan detected in groundwater (Table 3 ) are in the range of risk for aquatic life (Table 1) and testosterone was detected in concentration also above the drinking water criteria (Table 2).

\section{Raw and treated sewage}

The concentrations of each target compound in raw and treated effluents collected during 2010 and 2013 of the WWTPs located in the cities of Campinas and São José do Rio Preto in the state of São Paulo are presented in Figure 4 and in the SI section. Some emerging contaminants were still detected in relatively high concentrations after treatment process, but the average levels concentrations were below the levels suggested for secondary effluents by the Australian Guidelines for Water Recycling for caffeine (350 ng L-1), estrone (30 ng L $\left.{ }^{-1}\right)$, estriol (50 ng L $\left.{ }^{-1}\right)$, triclosan (350 $\left.\mathrm{ng} \mathrm{L}^{-1}\right)$, bisphenol A (200 $\left.\mu \mathrm{g} \mathrm{L}^{-1}\right)$ and atrazine $\left(40 \mu \mathrm{g} \mathrm{L} \mathrm{L}^{-1}\right){ }^{115}$

The wastewater treatment technology applied in São Paulo State Brazil (based on 57 raw and treated wastewater samples) was not effective for the removal of most of the investigated compounds (Figure 4). Conventional secondary treatments, such as aerated lagoon, activated sludge, upflow anaerobic sludge blanket (UASB), moving bed biofilm reactor, physical-chemical treatments, and others, are usually non-effective to remove these contaminants. ${ }^{115}$ Better removal rates are commonly achieved using tertiary treatments, such as photodegradation $\left(\mathrm{UV} / \mathrm{H}_{2} \mathrm{O}_{2}\right)$, Fenton $\left(\mathrm{Fe} / \mathrm{H}_{2} \mathrm{O}_{2}\right)$ or photo-Fenton (UV/Fe/ $\left.\mathrm{H}_{2} \mathrm{O}_{2}\right)$, ozone $\left(\mathrm{O}_{3}\right)$, electrochemical oxidation, granular activated carbon, or the use of membrane system (microfiltration, ultrafiltration, nanofiltration, reverse osmosis or bioreactor), ${ }^{115-117}$ but these treatments are not applied in WWTPs from São Paulo.

Caffeine and benzoylecgonine were detected in $100 \%$ of raw and treated effluents. Caffeine remained in the effluent at relatively high concentrations ( $2707 \mathrm{ng} \mathrm{L}^{-1}$ ) probably due to its high solubility in water and molecular stability. ${ }^{117,118}$ Furthermore, high levels of dissolved organic matter in water or wastewater decrease the efficiency of organic contaminants removal by conventional treatments.

The average of caffeine concentration found in treated wastewater (333 $\left.\mathrm{ng} \mathrm{L}^{-1}\right)$ is higher than the levels reported by Blackbeard et al. ${ }^{115}$ in a reuse water treatment plant in Australia (100 ng L $\left.\mathrm{L}^{-1}\right)$, but similar to those reported by Arzate et al. ${ }^{119}$ for a secondary wastewater treatment effluent in Spain $\left(409 \pm 52 \mathrm{ng} \mathrm{L}^{-1}\right)$. To enhance the removal of caffeine and other emerging contaminants from secondary effluents, the latter authors employed a photoFenton approach to reach up to $93 \%$ of caffeine removal.

Other contaminants of concern such as estrone, BPA, and atrazine were not efficiently removed by the conventional wastewater treatment (Figure 4) operating in

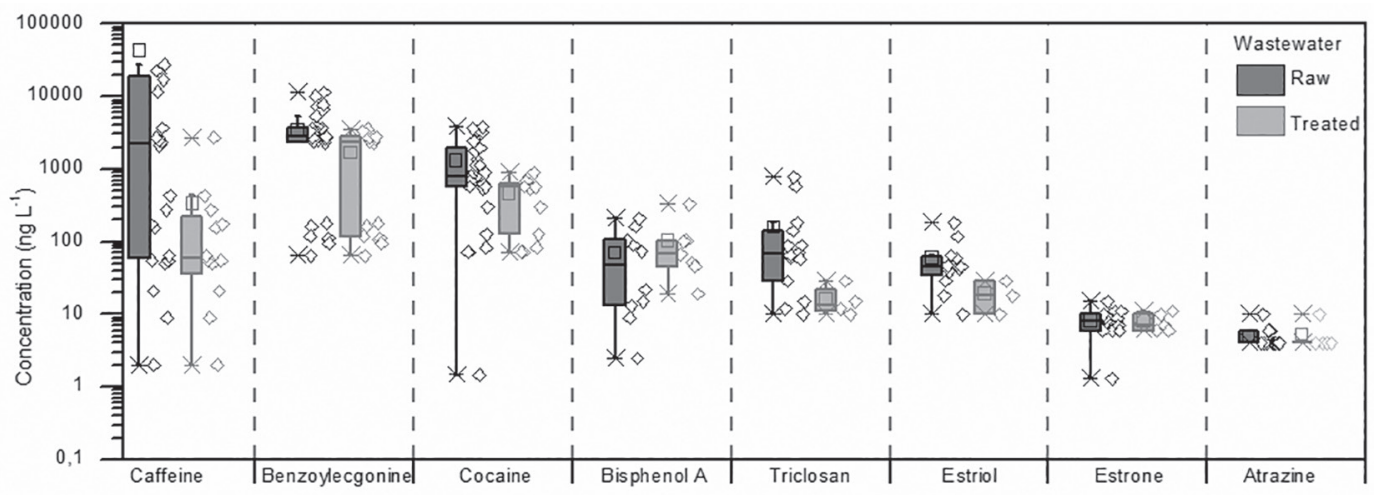

Figure 4. Box blot of the concentrations of emerging contaminants in raw and treated wastewater samples. 
Campinas and São José do Rio Preto cities. Estrone was more frequently detected, so it could be more stable than the other endogenous hormones. Triclosan levels in the treated wastewater detected in this work were similar to those reported for secondary effluent from a reuse water treatment in Australia $\left(20 \mathrm{ng} \mathrm{L}^{-1}\right){ }^{115}$

As observed for surface and drinking waters, the levels of cocaine in raw and treated wastewaters are lower in comparison to its major metabolite, benzoylecgonine. The low removal efficiency for benzoylecgonine during the wastewater treatment was also observed in India, where no significant differences between the concentrations in both influent and effluent were depicted. ${ }^{120}$ However, concentrations of benzoylecgonine in the raw wastewater investigated in this work were almost 50 times higher than those reported in India. In Spain, Bijlsma et al. ${ }^{121}$ reported levels of cocaine and benzoylecgonine in raw wastewater similar to those found in the present work. Despite the similar concentrations, the Spanish WWTP was able to remove almost $75 \%$ of these contaminants whereas in Brazil, a lower removal efficiency was observed to the treatment processes.

\section{Removal of anthropogenic activity indicators by wastewater} and drinking water plants

Figure 5 shows an overview of average caffeine concentration in drinking waters collected in 13 cities in the state of São Paulo (Campinas, Atibaia, Barueri, Cerquilho, Guarulhos, Rio Preto, Piracicaba, São Bernardo, Diadema, Osasco, Carapicuíba, Franco da Rocha and São Paulo), in surface waters from 10 rivers (Atibaia, Capivari, Jundiaí, Sorocaba, Baixo Cotia, Preto, Corumbataí, Piracicaba, Anhumas Creek and Pinheiro Creek) and 4 reservoirs (Salto Grande, Tanque Grande, Cantareira and Guarapiranga) and in treated and raw sewages measured 5 WWTPs located in Campinas and São José do Rio Preto cities.
It is possible to observe that the median concentration of caffeine in inland surface waters (approximately $1000 \mathrm{ng} \mathrm{L}^{-1}$ ) is almost ten times higher than the median concentration reported for treated wastewaters. Thus, this behavior is clear evidence of the role of untreated sewage discharges, since the caffeine content in the raw waste may be completely transferred to surface waters without any removal step in WWTP. This result shows that WWTP effluents are not the main sources of surface water contamination in the state of São Paulo. On the contrary, this role should be attributed to the direct disposal of raw wastewater into receiving waters. This same conclusion was made by Sodré et al., ${ }^{122}$ who investigated the presence of caffeine and bisphenol A in drinking waters from the city of Campinas. The authors showed that high levels of caffeine in drinking waters were related to the low rates of sewage treatment in the region. In the present work, the data portrayed in Figure 5 not only corroborate the result raised by Sodré et al., ${ }^{122}$ but also evidenced that the same route of contamination is prevalent in other cities of the state.

In the Brazilian scenario, the term reuse water holds an underlying meaning, which is the classical indirect and unplanned reuse water. Nowadays, the watersheds are used to solve the supply demands in one region at the expense of another. A water body is used as source water for one city, which also inputs its sewage downstream (mostly untreated sewage). Further, downstream another city uses the same river to supply their population with drinking water. As a result, some cities face the challenge of getting a drinking water treatment plant (DWTP) intended for treating surface water that actually has to treat water with the quality of sewage water.

Caffeine has been used as a marker of human activities since the work of Siegener and Chen, ${ }^{123}$ which investigated how pharmaceuticals were entering Boston Harbor.

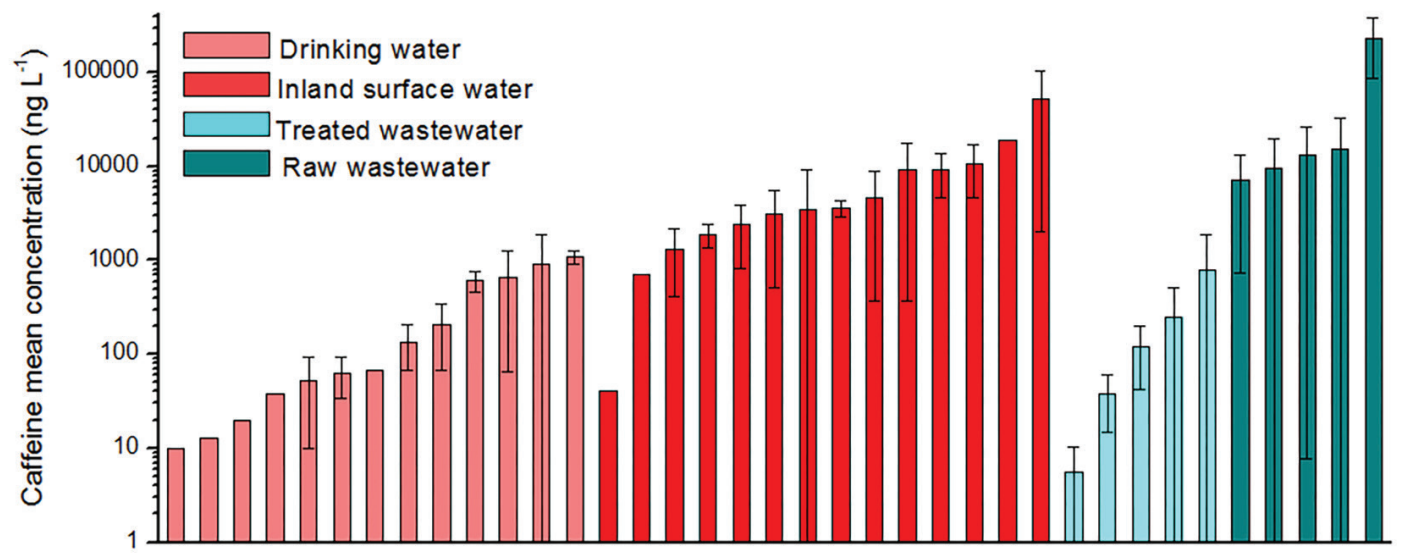

Figure 5. Average caffeine concentrations in drinking water samples collected in 13 cities of the state of São Paulo $(\mathrm{n}=231), 14$ surface water samples $(\mathrm{n}=203)$ and 5 WWTPs $(\mathrm{n}=57)$. 
The authors proposed the use of caffeine as a tracer of anthropogenic inputs into marine systems as highly caffeinated freshwaters were mixed with uncontaminated sea waters. Since then, a number of reports have consolidated the use of caffeine as an indicator of wastewater impacted waters, ${ }^{124-127}$ including in Brazil. ${ }^{90,122,128,129}$

Figure 6 shows concentrations of cocaine and benzoylecgonine determined in drinking water samples collected in 5 cities of the state of São Paulo (Limeira, Campinas, Espírito Santo do Pinhal, Santa Barbara d'Oeste and Piracicaba), in surface water samples from 16 different rivers, and in treated and raw wastewater samples collected in 2 WWTPs of the city of Campinas.

The concentrations of benzoylecgonine were higher than cocaine in all analyzed samples. This could be related to the excretion metabolism of this illicit drug since $25 \%$ of the consumed crack/cocaine is excreted in urine as benzoylecgonine. ${ }^{130}$ In addition, considering that the main source of illicit drugs to the environment is the human excretion, a variety of studies show that benzoylecgonine is more stable than cocaine under different environmental conditions such as temperature and $\mathrm{pH} .{ }^{67,121,131}$
Different removal efficiencies for cocaine and benzoylecgonine were observed for each conventional WWTP evaluated. While a given WWTP could reduce cocaine in $55 \%$, the metabolite concentration was only $8 \%$ reduced; the other WWTP was able to decrease more than $95 \%$ of the benzoylecgonine concentration and almost $100 \%$ of the parental drug. ${ }^{15}$ These results may suggest that the concentration of illicit drugs, mainly benzoylecgonine, observed in surface and drinking water samples come from discharges of both treated and raw wastewaters into aquatic bodies. The differences observed during the treatment processes could also be observed in DWTPs. Benzoylecgonine concentrations in drinking water samples were similar to those observed in surface water samples, whereas cocaine concentration, when detected, was almost 10-fold less.

As for benzoylecgonine, many other emerging contaminants (e.g., psychoactive substances) pose a challenge to be removed by conventional treatment processes employed in WWTPs and DWTPs notably due to their high hydrophilicity. The use of water indicators based on different types of emerging contaminants have been
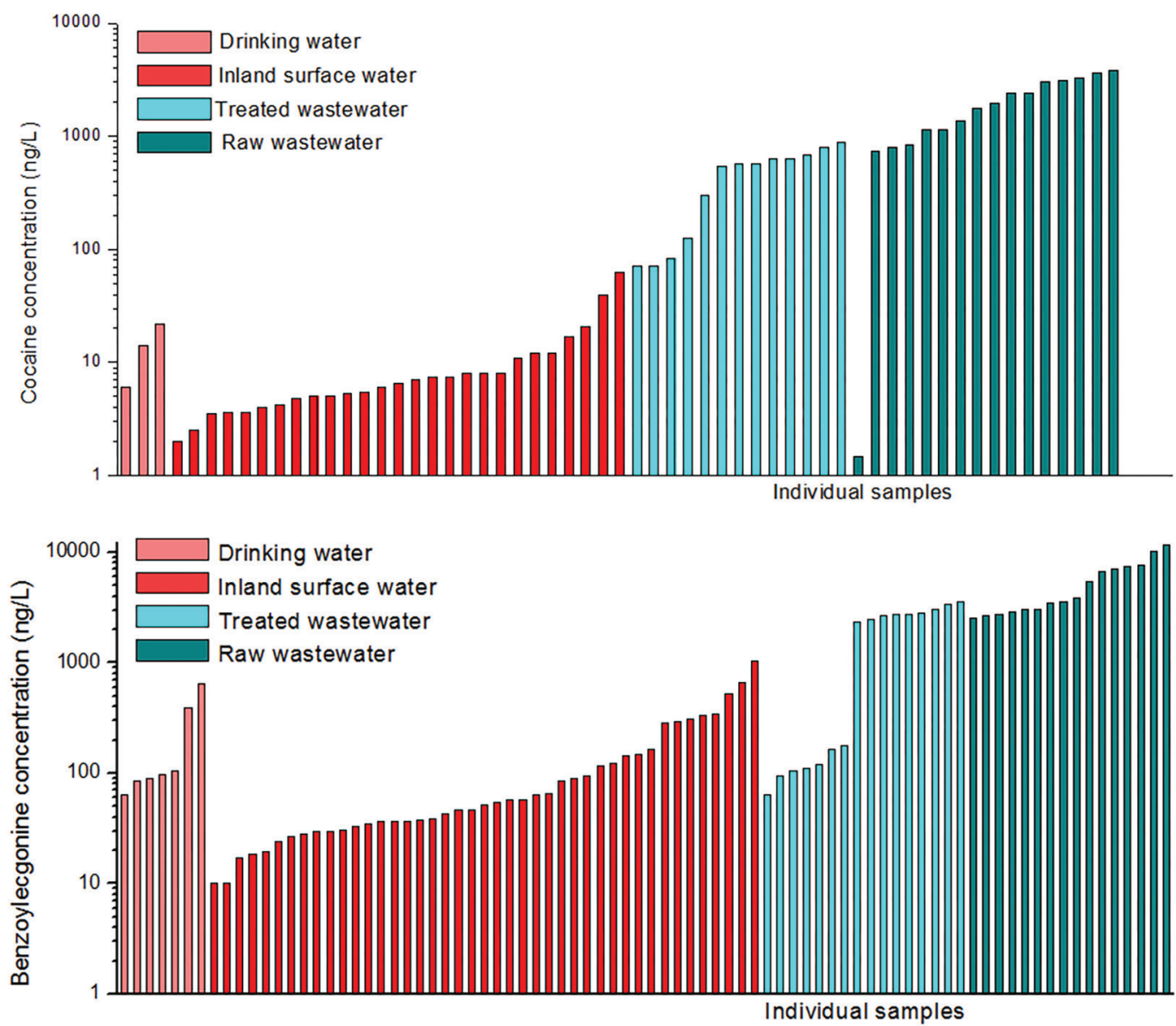

Figure 6. Concentrations of cocaine and benzoylecgonine in drinking water samples from 5 cities, in surface water samples from 16 different rivers, and in treated and raw wastewater samples collected in 2 WWTPs. 
considered to improve monitoring and to complement the current strategies related to watersheds management. ${ }^{132,133}$ Considering the stability and the high frequency of detection of benzoylecgonine in environmental aquatic matrices, this substance may be a reliable biomarker for both surface and drinking waters, mainly as an indicator of the sanitation conditions, since this cocaine metabolite can persist in the aquatic environment even after two weeks from the discharge ${ }^{67}$ and it has been also detected in surface and drinking waters in countries with better sanitation index in comparison with Brazil. ${ }^{134-136}$

\section{Conclusions}

The set of data used in this work (58 target compounds and 708 samples collected from 2006 to 2015) represented the snapshot of the contamination in the state of São Paulo. Some compounds such as caffeine, estrone, 17 $\beta$-estradiol, $17 \alpha$-ethynylestradiol, bisphenol A, atrazine, carbendazim, fipronil, malathion and imidacloprid were highlighted as priority concern among the studied contaminants considering the frequency of detection and the number of positive samples above WQC.

The preliminary risk assessment for aquatic life protection were identified for caffeine, paracetamol, diclofenac, $17 \alpha$-ethynylestradiol, 17 $\beta$-estradiol, estriol, estrone, testosterone, triclosan, 4-n-nonylphenol, bisphenol A, atrazine, azoxystrobin, carbendazim, fipronil, imidacloprid, malathion and tebuconazole, but considering the drinking water criteria available in the literature no adverse effects to human health were expected to the studied scenario, except for $17 \beta$-estradiol.

Due to their stability in water and high frequency of detection in all studied aquatic matrices, caffeine and benzoylecgonine showed as good anthropogenic indicators, especially to the regions with high-density population and poor sanitation system.

\section{Supplementary Information}

Concentrations of the target substances in each sample $(n=708)$ collected from 2006 to 2015 as well as information about sampling location, year of sampling, instrumental tools and method used to determine the contaminants are given as supplementary information available free of charge at http://jbcs.sbq.org.br.

\section{Acknowledgments}

The authors are thankful to FAPESP (process No. 2007/58449-2 and 2014/24740-6) and INCTAA (CNPQ grants 573894/2008-6 and 465768/2014-8, and FAPESP grants 2008/57808-1 and 2014/50951-4) for financial support. The authors also thank Eduardo Maia Paiva for the assistance with the graphical abstract.

\section{References}

1. Richardson, S. D.; Kimura, S. Y.; Anal. Chem. 2016, 88, 546.

2. Desbrow, C.; Routledge, E. J.; Brighty, G. C.; Sumpter, J. P.; Waldock, M.; Environ. Sci. Technol. 1998, 32, 1549.

3. Purdom, C. E.; Hardiman, P. A.; Bye, V. V. J.; Eno, N. C.; Tyler, C. R.; Sumpter, J. P.; Chem. Ecol. 1994, 8, 275.

4. Sauvé, S.; Desrosiers, M.; Chem. Cent. J. 2014, 8, 15.

5. Yang, Y.; Sik, Y.; Kim, K.; Kwon, E. E.; Fai, Y.; Sci. Total Environ. 2017, 597, 303.

6. Tiedeken, E. J.; Tahar, A.; McHugh, B.; Rowan, N. J.; Sci. Total Environ. 2017, 574, 1140.

7. Montagner, C. C.; Vidal, C.; Acayaba, R. D.; Quim. Nova 2017, 40, 1094.

8. Sousa, J. C. G.; Ribeiro, A. R.; Barbosa, M. O.; Pereira, M. F. R.; Silva, A. M. T.; J. Hazard. Mater. 2017, 344, 146.

9. Barbosa, M. O.; Moreira, N. F. F.; Ribeiro, A. R.; Pereira, M. F. R.; Silva, A. M. T.; Water Res. 2016, 94, 257.

10. Petrie, B.; Barden, R.; Kasprzyk-Hordern, B.; Water Res. 2014, 72,3 .

11. von der Ohe, P. C.; Dulio, V.; Slobodnik, J.; de Deckere, E.; Kühne, R.; Ebert, R. U.; Ginebreda, A.; de Cooman, W.; Schüürmann, G.; Brack, W.; Sci. Total Environ. 2011, 409, 2064.

12. Agência Nacional de Águas (ANA); Conjuntura dos Recursos Hídricos no Brasil; ANA: Brasília, 2017, available at http://conjuntura.ana.gov.br/static/media/conjuntura completo.27432e70.pdf, accessed in November 2018.

13. Umbuzeiro, G. A.; Guia de Potabilidade para Substâncias Químicas; ABES: São Paulo, 2012, p.144.

14. Miller, J. N.; Miller, J. C.; Multivariate Analysis; Pearson/ Prentice Hall: New Jersey, 2005, p. 285.

15. Campestrini, I.; Jardim, W. F.; Sci. Total Environ. 2017, 576, 374.

16. Montagner, C. C.; Vidal, C.; Acayaba, R. D.; Jardim, W. F.; Jardim, I. C. S. F.; Umbuzeiro, G. A.; Anal. Methods 2014, 6, 6668.

17. Locatelli, M. A. F.; Sodré, F. F.; Jardim, W. F.; Arch. Environ. Contam. Toxicol. 2011, 60, 385.

18. Jardim, W. F.; Montagner, C. C.; Pescara, I. C.; Umbuzeiro, G. A.; di Dea Bergamasco, A. M.; Eldridge, M. L.; Sodré, F. F.; Sep. Purif. Technol. 2012, 84, 3.

19. Machado, K. C.; Grassi, M. T.; Vidal, C.; Pescara, I. C.; Jardim, W. F.; Fernandes, A. N.; Sodré, F. F.; Almeida, F. V.; Santana, J. S.; Canela, M. C.; Nunes, C. R. O.; Bichinho, K. M.; Severo, F. J. R.; Sci. Total Environ. 2016, 572, 138. 
20. Montagner, C. C.; Jardim, W. F.; J. Braz. Chem. Soc. 2011, 22, 1452.

21. Hernando, M. D.; Mezcua, M.; Fernandez-Alba, A. R.; Barceló, D.; Talanta 2006, 69, 334.

22. Moltmann, J. F.; Liebig, M.; Knacker, T.; Keller, M.; Scheurer, M.; Ternes, T.; Relevance of Endocrine Disrupting Substances and Pharmaceuticals in Surface Waters, Report UBA-FB 205 24 205; Dessau, Deutschland, 2007.

23. Swiss Centre for Applied Ecotoxicology, Ecotox Centre; Proposals for Acute and Chronic Quality Standards, available at http://www.ecotoxcentre.ch/expert-service/quality-standards/ proposals-for-acute-and-chronic-quality-standards/, accessed in November 2018.

24. Canadian Council of Ministers of the Environment (CCME); Canadian Water Quality Guidelines for the Protection of Aquatic Life: Bromacil; Canadian Council of Ministers of the Environment, Winnipeg, 1999, available at http://ceqg-rcqe. ccme.ca/download/en/146?redir=1542978917, accessed in November 2018.

25. Institut National de l'Environnement Industriel et des Risques (INERIS); Environnement, Normes de Qualité Environnementale (NQE) et Valeurs Guides Environnementales $(V G E)$, available at https://substances.ineris.fr/fr/page/9, accessed in November 2018.

26. Lippi, A. M. F.; Andrade, D. G.; Bovo, J.; Nogueira, L.; Pinto, M. M.; Revinter 2014, 7, 24.

27. Moschet, C.; Wittmer, I.; Simovic, J.; Junghans, M.; Piazzoli, A.; Singer, H.; Stamm, C.; Leu, C.; Hollender, J.; Environ. Sci. Technol. 2014, 48, 5423.

28. Carlsson, C.; Johansson, A. K.; Alvan, G.; Bergman, K.; Kühler, T.; Sci. Total Environ. 2006, 364, 88.

29. Jones, O. A. H.; Voulvoulis, N.; Lester, J. N.; Water Res. 2002, $36,5013$.

30. Kümmerer, K.; Clin. Microbiol. Infect. 2003, 9, 1203.

31. Komori, K.; Suzuki, Y.; Minamiyama, M.; Harada, A.; Environ. Monit. Assess. 2013, 185, 4529.

32. Stuer-Lauridsen, F.; Birkved, M.; Hansen, L. P.; Lützhøft, H.-C. H.; Halling-Sørensen, B.; Chemosphere 2000, 40, 783.

33. Caldwell, D. J.; Mastrocco, F.; Hutchinson, T. H.; Länge, R.; Heijerick, D.; Janssen, C.; Anderson, P. D.; Sumpter, J. P.; Environ. Sci. Technol. 2008, 42, 7046.

34. Slobodnik, J.; Mrafkova, L.; Carere, M.; Ferrara, F.; Pennelli, B.; Schüürmann, G.; von der Ohe, P. C.; TrAC, Trends Anal. Chem. 2012, 41, 133.

35. Wittmer, I. K.; Scheidegger, R.; Bader, H.-P.; Singer, H.; Stamm, C.; Sci. Total Environ. 2011, 409, 920.

36. Salis, S.; Testa, C.; Roncada, P.; Armorini, S.; Rubattu, N.; Ferrari, A.; Miniero, R.; Brambilla, G.; J. Environ. Sci. Health, Part B 2017, 52, 699.

37. Palma, G.; Sánchez, A.; Olave, Y.; Encina, F.; Palma, R.; Barra, R.; Chemosphere 2004, 57, 763.
38. Masiá, A.; Campo, J.; Vázquez-Roig, P.; Blasco, C.; Picó, Y.; J. Hazard. Mater. 2013, 263, 95.

39. Burkhardt, M.; Kupper, T.; Hean, S.; Haag, R.; Schmid, P.; Kohler, M.; Boller, M.; Water Sci. Technol. 2007, 56, 63.

40. Chen, Z.-F.; Ying, G.-G.; Liu, Y.-S.; Zhang, Q.-Q.; Zhao, J.-L.; Liu, S.-S.; Chen, J.; Peng, F.-J.; Lai, H.-J.; Pan, C.-G.; Water Res. 2014, 58, 269.

41. Potter, T. L.; Bosch, D. D.; Strickland, T. C.; Sci. Total Environ. 2014, 490, 1.

42. Lefrancq, M.; Jadas-Hécart, A.; la Jeunesse, I.; Landry, D.; Payraudeau, S.; Sci. Total Environ. 2017, 587, 75.

43. Kahle, M.; Buerge, I. J.; Hauser, A.; Müller, M. D.; Poiger, T.; Environ. Sci. Technol. 2008, 42, 7193.

44. Stamatis, N.; Hela, D.; Konstantinou, I.; J. Hazard. Mater. 2010 , 175,829 .

45. de Gerónimo, E.; Aparicio, V. C.; Bárbaro, S.; Portocarrero, R.; Jaime, S.; Costa, J. L.; Chemosphere 2014, 107, 423.

46. da Silva, D. R. O.; de Avila, L. A.; Agostinetto, D.; dal Magro, T.; de Oliveira, E.; Zanella, R.; Noldin, J. A.; Ciência Rural 2009, 39, 2383.

47. Battaglin, W. A.; Sandstrom, M. W.; Kuivila, K. M.; Kolpin, D. W.; Meyer, M. T.; Water, Air, Soil Pollut. 2011, 218, 307.

48. Mnif, W.; Hassine, A. I. H.; Bouaziz, A.; Bartegi, A.; Thomas, O.; Roig, B.; Int. J. Environ. Res. Public Health 2011, 8, 2265.

49. Stone, W. W.; Gilliom, R. J.; Ryberg, K. R.; Environ. Sci. Technol. 2014, 48, 11025.

50. Bonansea, R. I.; Amé, M. V.; Wunderlin, D. A.; Chemosphere 2013, 90, 1860.

51. Pereira, W. E.; Moody, J. A.; Hostettler, C. E.; Rostad, C. E.; Leiker, T. J.; Concentrations and Mass Transport of Pesticides and Organic Contaminants in the Mississippi River and Some of Its Tributaries, USGS Report-1987-89 and 1991-92; U.S. Geological Survey Open-File Report 94-376: Denver, 1995.

52. Bussan, D. D.; Ochs, C. A.; Jackson, C. R.; Anumol, T.; Snyder, S. A.; Cizdziel, J. V.; Environ. Monit. Assess. 2017, 189, 73.

53. Moreno-González, R.; Campillo, J. A.; García, V.; León, V. M.; Chemosphere 2013, 92, 247.

54. Masiá, A.; Ibáñez, M.; Blasco, C.; Sancho, J. V.; Picó, Y.; Hernández, F.; Anal. Chim. Acta 2013, 761, 117.

55. Bethsass, J.; Colangelo, A.; Int. J. Occup. Environ. Health 2006, $12,260$.

56. Machado, C. S.; Fregonesi, B. M.; Alves, R. I. S.; Tonani, K. A. A.; Sierra, J.; Martinis, B. S.; Celere, B. S.; Mari, M.; Schuhmacher, M.; Nadal, M.; Domingo, J. L.; Segura-Muñoz, S.; Environ. Sci. Pollut. Res. 2017, 24, 20160.

57. Machado, C. S.; Alves, R. I. S.; Fregonesi, B. M.; Tonani, K. A. A.; Martinis, B. S.; Sierra, J.; Nadal, M.; Domingo, J. L.; Segura-Muñoz, S.; Procedia Eng. 2016, 162, 230.

58. Kolpin, D. W.; Skopec, M.; Meyer, M. T.; Furlong, E. T.; Zaugg, S. D.; Sci. Total Environ. 2004, 328, 119. 
59. Ide, A. H.; Osawa, R. A.; Marcante, L. O.; Pereira, J. C.; de Azevedo, J. C. R.; Clean: Soil, Air, Water 2017, 45, 1700334.

60. Hu, X.-L.; Bao, Y.-F.; Hu, J.-J.; Liu, Y.-Y.; Yin, D.-Q.; Environ. Sci. Pollut. Res. 2017, 24, 14889.

61. Tewari, S.; Jindal, R.; Kho, Y. L.; Eo, S.; Choi, K.; Chemosphere 2013, 91, 697.

62. Bedoux, G.; Roig, B.; Thomas, O.; Dupont, V.; le Bot, B.; Environ. Sci. Pollut. Res. 2012, 19, 1044.

63. Kantiani, L.; Farré, M.; Asperger, D.; Rubio, F.; González, S.; de Alda, M. J. L.; Petrović, M.; Shelver, W. L.; Barceló, D.; J. Hydrol. 2008, 361, 1.

64. Spongberg, A. L.; Witter, J. D.; Acuña, J.; Vargas, J.; Murillo, M.; Umaña, G.; Gómez, E.; Perez, G.; Water Res. 2011, 45, 6709.

65. Campanha, M. B.; Awan, A. T.; de Sousa, D. N. R.; Grosseli, G. M.; Mozeto, A. A.; Fadini, P. S.; Environ. Sci. Pollut. Res. 2015, 22, 7936.

66. dos Santos, M. M.; Brehm, F. A.; Filippe, T. C.; Knapik, H. G.; de Azevedo, J. C. R.; RBRH 2016, 21, 603.

67. McCall, A.-K.; Bade, R.; Kinyua, J.; Lai, F. Y.; Thai, P. K.; Covaci, A.; Bijlsma, L.; van Nuijs, A. L. N.; Ort, C.; Water Res. 2016, 88, 933.

68. Feitosa, R. S.; Sodré, F. F.; Maldaner, A. O.; Quim. Nova 2013, 36, 291.

69. Zuccato, E.; Castiglioni, S.; Bagnati, R.; Chiabrando, C.; Grassi, P.; Fanelli, R.; Water Res. 2008, 42, 961.

70. Kasprzyk-Hordern, B.; Dinsdale, R. M.; Guwy, A. J.; Anal. Bioanal. Chem. 2008, 391, 1293.

71. Huerta-Fontela, M.; Galceran, M. T.; Ventura, F.; Anal. Chem. 2007, 79, 3821.

72. van Nuijs, A. L. N.; Pecceu, B.; Theunis, L.; Dubois, N.; Charlier, C.; Jorens, P. G.; Bervoets, L.; Blust, R.; Neels, H.; Covaci, A.; Environ. Pollut. 2009, 157, 123.

73. Thomas, K. V.; da Silva, F. M. A.; Langford, K. H.; de Souza, A. D. L.; Nizzeto, L.; Waichman, A. V.; J. Am. Water Resour. Assoc. 2014, 50, 302.

74. Quadra, G. R.; de Souza, H. O.; Costa, R. S.; Fernandez, M. A. S.; Environ. Sci. Pollut. Res. 2017, 24, 1200.

75. Torres, N. H.; Aguiar, M. M.; Ferreira, L. F. R.; Américo, J. H. P.; Machado, Â. M.; Cavalcanti, E. B.; Tornisielo, V. L.; Environ. Monit. Assess. 2015, 187, 379.

76. Moreira, D. S.; Aquino, S. F.; Afonso, R. J. C. F.; Santos, E. P. P. C.; de Pádua, V. L.; Environ. Technol. 2009, 30, 1041.

77. Lopes, L. G.; Marchi, M. R. R.; Souza, J. B. G.; Moura, J. A.; Lorenzon, C. S.; Cruz, C.; Amaral, L. A.; Quim. Nova 2010, 33,639 .

78. Fromme, H.; Küchler, T.; Otto, T.; Pilz, K.; Müller, J.; Wenzel, A.; Water Res. 2002, 36, 1429.

79. Fatoki, O. S.; Vernon, F.; Sci. Total Environ. 1990, 95, 227.

80. Vitali, M.; Guidotti, M.; Macilenti, G.; Cremisini, C.; Environ. Int. 1997, 23, 337.
81. Jin, X.; Jiang, G.; Huang, G.; Liu, J.; Zhou, Q.; Chemosphere 2004, 56, 1113.

82. Santhi, V. A.; Sakai, N.; Ahmad, E. D.; Mustafa, A. M.; Sci. Total Environ. 2012, 427, 332.

83. Huang, Y. Q.; Wong, C. K. C.; Zheng, J. S.; Bouwman, H.; Barra, R.; Wahlström, B.; Neretin, L.; Wong, M. H.; Environ. Int. 2012, 42, 91.

84. Moreira, M.; Aquino, S.; Coutrim, M.; Silva, J.; Afonso, R.; Environ. Technol. 2011, 32, 1409.

85. Froehner, S.; Machado, K. S.; Falcão, F.; Monnich, C.; Bessa, M.; Water, Air, Soil Pollut. 2011, 215, 251.

86. Barbosa, A. M. C.; Solano, M. L. M.; Umbuzeiro, G. A.; Front. Public Health 2015, 3, DOI 10.3389/fpubh.2015.00246.

87. New Zealand Ministry of Health; Drinking-Water Standards for New Zealand 2005 (Revised 2008); Ministry of Health, Wellington, 2008.

88. Brand, W.; de Jongh, C. M.; van der Linden, S. C.; Mennes, W.; Puijker, L. M.; van Leeuwen, C. J.; van Wezel, A. P.; Schriks, M.; Heringa, M. B.; Environ. Int. 2013, 55, 109.

89. Glassmeyer, S. T.; Furlong, E. T.; Kolpin, D. W.; Cahill, J. D.; Zaugg, S. D.; Werner, S. L.; Meyer, M. T.; Kryak, D. D.; Environ. Sci. Technol. 2005, 39, 5157.

90. Montagner, C. C.; Umbuzeiro, G. A.; Pasquini, C.; Jardim, W. F.; Environ. Sci.: Processes Impacts 2014, 16, 1866.

91. Sodré, F. F.; Santana, J. S.; Sampaio, T. R.; Brandão, C. C. S.; J. Braz. Chem. Soc. 2018, 29, 1854.

92. Benotti, M. J.; Trenholm, R. A.; Vanderford, B. J.; Holady, J. C.; Stanford, B. D.; Snyder, S. A.; Environ. Sci. Technol. 2009, 43, 597.

93. Padhye, L. P.; Yao, H.; Kung'u, F. T.; Huang, C.-H.; Water Res. 2014, 51, 266.

94. Klarich, K. L.; Pflug, N. C.; DeWald, E. M.; Hladik, M. L.; Kolpin, D. W.; Cwiertny, D. M.; LeFevre, G. H.; Environ. Sci. Technol. Lett. 2017, 4, 168.

95. Van Toan, P.; Sebesvari, Z.; Bläsing, M.; Rosendahl, I.; Renaud, F. G.; Sci. Total Environ. 2013, 452-453, 28.

96. Yavuz, M.; Oggioni, M.; Yetis, U.; Dilek, F. B.; Desalin. Water Treat. 2015, 53, 3253.

97. Servos, M. R.; Smith, M.; McInnis, R.; Burnison, B. K.; Lee, B.-H.; Seto, P.; Backus, S.; Water Qual. Res. J. Can. 2007, 42, 130.

98. Huerta-Fontela, M.; Galceran, M. T.; Ventura, F.; Environ. Sci. Technol. 2008, 42, 6809.

99. Boleda, M. R.; Huerta-Fontela, M.; Ventura, F.; Galceran, M. T.; Chemosphere 2011, 84, 1601.

100. Kuster, M.; López de Alda, M. J.; Hernando, M. D.; Petrovic, M.; Martín-Alonso, J.; Barceló, D.; J. Hydrol. 2008, 358, 112 .

101. Kuch, H. M.; Ballschmiter, K.; Environ. Sci. Technol. 2001, 35 , 3201.

102. Cai, M.-Q.; Wang, R.; Feng, L.; Zhang, L.-Q.; Environ. Sci. Pollut. Res. 2015, 22, 1854. 
103. Fan, Z.; Hu, J.; An, W.; Yang, M.; Environ. Sci. Technol. 2013, 47, 10841.

104. Shao, B.; Hu, J.; Yang, M.; An, W.; Tao, S.; Arch. Environ. Contam. Toxicol. 2005, 48, 467.

105. Casajuana, N.; Lacorte, S.; Chromatographia 2003, 57, 649.

106. Serôdio, P.; Nogueira, J. M. F.; Water Res. 2006, 40, 2572.

107. Loraine, G. A.; Pettigrove, M. E.; Environ. Sci. Technol. 2006, 40, 687.

108. Dujaković, N.; Grujić, S.; Radišić, M.; Vasiljević, T.; Laušević, M.; Anal. Chim. Acta 2010, 678, 63.

109. Schipper, P. N. M.; Vissers, M. J. M.; van der Linden, A. M. A.; Water Sci. Technol. 2008, 57, 1277.

110. Loos, R.; Locoro, G.; Comero, S.; Contini, S.; Schwesig, D.; Werres, F.; Balsaa, P.; Gans, O.; Weiss, S.; Blaha, L.; Bolchi, M.; Manfred, B.; Water Res. 2010, 44, 4115.

111. Rabiet, M.; Togola, A.; Brissaud, F.; Seidel, J. L.; Budzinski, H.; Elbaz-Poulichet, F.; Environ. Sci. Technol. 2006, 40, 5282.

112. Fram, M. S.; Belitz, K.; Sci. Total Environ. 2011, 409, 3409.

113. Reemtsma, T.; Alder, L.; Banasiak, U.; Water Res. 2013, 47, 5535.

114. Binelli, A.; Marisa, I.; Fedorova, M.; Hoffmann, R.; Riva, C.; Aquat. Toxicol. 2013, 140-141, 268.

115. Blackbeard, J.; Lloyd, J.; Magyar, M.; Mieog, J.; Linden, K. G.; Lester, Y.; Environ. Sci.: Water Res. Technol. 2016, 2, 213.

116. Hofman-Caris, C. H. M.; Siegers, W. G.; van de Merlen, K.; de Man, A. W. A.; Hofman, J. A. M. H.; Chem. Eng. J. 2017, 327, 514.

117. Bui, X. T.; Vo, T. P. T.; Ngo, H. H.; Guo, W. S.; Nguyen, T. T.; Sci. Total Environ. 2016, 563-564, 1050.

118. Zhang, D. Q.; Hua, T.; Gersberg, R. M.; Zhu, J.; Ng, W. J.; Tan, S. K.; Chemosphere 2013, 90, 1568.

119. Arzate, S.; García Sánchez, J. L.; Soriano-Molina, P.; Casas López, J. L.; Campos-Mañas, M. C.; Agüera, A.; Sánchez Pérez, J. A.; Chem. Eng. J. 2017, 316, 1114.

120. Subedi, B.; Balakrishna, K.; Sinha, R. K.; Yamashita, N.; Balasubramanian, V. G.; Kannan, K.; Biochem. Pharmacol. 2015, 3, 2882.

121. Bijlsma, L.; Serrano, R.; Ferrer, C.; Tormos, I.; Hernández, F.; Sci. Total Environ. 2014, 487, 703.
122. Sodré, F. F.; Locatelli, M. A. F.; Jardim, W. F.; Water, Air, Soil Pollut. 2010, 206, 57.

123. Siegener, R.; Chen, R. F.; Analysis of Environmental Endocrine Disruptors, vol. 747; Keith, L. H.; Jones-Lepp, T. L.; Needham, L. L., eds.; American Chemical Society: Washington, DC, USA, 1999, ch. 8, p. 125.

124. Young, T. A.; Heidler, J.; Matos-Pérez, C. R.; Sapkota, A.; Toler, T.; Gibson, K. E.; Schwab, K. J.; Halden, R. U.; Environ. Sci. Technol. 2008, 42, 3335.

125. Vystavna, Y.; le Coustumer, P.; Huneau, F.; Environ. Monit. Assess. 2013, 185, 3581.

126. Spence, P. L.; Environ. Health Insights 2015, 9, 29.

127. Paíga, P.; Delerue-Matos, C.; Mar. Pollut. Bull. 2017, 120, 355.

128. Ferreira, A. P.; Cad. Saúde Pública 2005, 21, 1884.

129. Gonçalves, E. S.; Rodrigues, S. V.; da Silva-Filho, E. V.; Rev. Ambient. Água 2017, 12, 192.

130. Sodré, F. F.; Feitosa, R. S.; Jardim, W. F.; Maldaner, A. O.; J. Braz. Chem. Soc. 2018, 29, 2287.

131. van Nuijs, A. L. N.; Castiglioni, S.; Tarcomnicu, I.; Postigo, C.; de Alda, M. L.; Neels, H.; Zuccato, E.; Barcelo, D.; Covaci, A.; Sci. Total Environ. 2011, 409, 3564.

132. Naidu, R.; Jit, J.; Kennedy, B.; Arias, V.; Chemosphere 2016, $154,385$.

133. Daneshvar, A.; Aboulfadl, K.; Viglino, L.; Broséus, R.; Sauvé, S.; Madoux-Humery, A. S.; Weyhenmeyer, G. A.; Prévost, M.; Chemosphere 2012, 88, 131.

134. Rosa Boleda, M.; Huerta-Fontela, M.; Ventura, F.; Galceran, M. T.; Chemosphere 2011, 84, 1601.

135. Mendoza, A.; Rodríguez-Gil, J. L.; González-Alonso, S.; Mastroianni, N.; López de Alda, M.; Barceló, D.; Valcárcel, Y.; Environ. Int. 2014, 70, 76.

136. Yadav, M. K.; Short, M. D.; Aryal, R.; Gerber, C.; van den Akker, B.; Saint, C. P.; Water Res. 2017, 124, 713.

Submitted: July 23, 2018

Published online: November 27, 2018 